\title{
أحاديث فضيلة الزهد في كتاب سَيْر السالكين للشيخ عبد الصمد الفَلِمْبَاِين \\ دراسة تحليلية نقدية
}

TAUFIQ HIDAYAT, FADHLI ANANDA, MUHAMMAD SUTRISNO BIN SYAMSUIR

International Islamic University Malaysia

\begin{abstract}
Abstrak
This research examines the Hadith Zuhud (Asceticism) in the Sayr Al-Salikiin of Abdus Somad Al-Falimbani in terms of matn (their text) and sanad (chain of narration). A brief introduction of the narrator of the hadith is also given. Attestation of the hadith in other books is examined and the status of hadith is determined whether they remain daif (weak) or upgraded to be hasan (valid). The researcher used the inductive method to collect hadith Zuhud (Asceticism) in the Sayr Al-Salikiin of Abdus Somad Al-Falimbani as well as the critical approach on the attestation in other books and determine the status of the hadith and used the analytical method to conclude on some jurisprudence of the Hadith. As a result, the researcher found most of hadith in the Sayr Al-Salikiin are eligible to be upgraded into hasan. The rest remain daif due the unavailable attestation or weak narrator chain. The hadiths in the Sayr Al-Salikiin book about Zuhud (Asceticism) are thirty. But, The hadiths about advantages of asceticism five. hadiths that reach to the hasan level are one. And the rest remain daif due the unavailable attestation in another book or weaken narrator.
\end{abstract}

\section{Keyword}

Hadith, Zuhud, Abdus Somad Al-Falimbani, Syar Al-Salikiin

\section{I}

فقد نفى بعض الناس أهمية الزهد في الإسلام نفياً قاطعاً، واعتبر أن الزهد بدعة دخيلة في الإسلام،

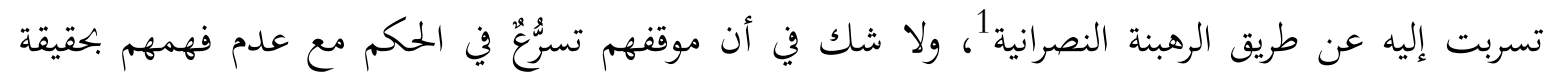
الإسلام. فلو رجع هؤلاء المنكرون إلى أحاديث رسول الله صلى الله عليه وسلم لوجدوا أنه عليه الصلاة والسلام يدعو إلى الزهد صراحة، ويعتبر أن الزهد وسيلة لنيل محبة الله تعالى. فقد روى سهل بل بن سعد الساعدي رضي رضي الله عنه قال: جاء رجل إلى رسول الله صلى الله عليه وسلم فقال: يا رسول الله! دُلَّني على عمل إذا عملته أحبني

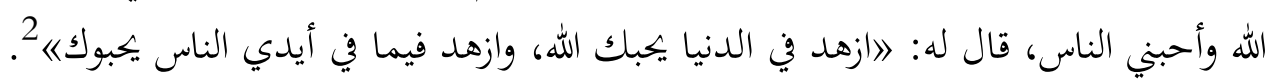

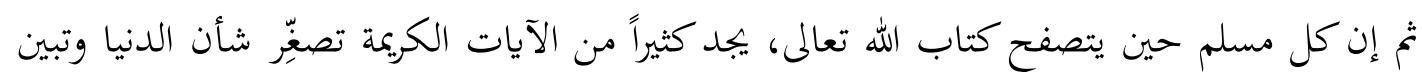

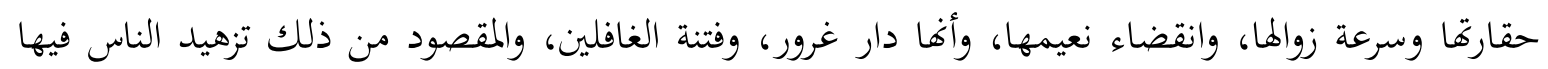

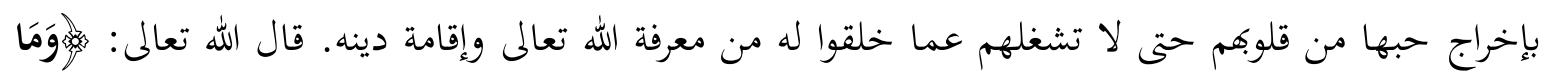

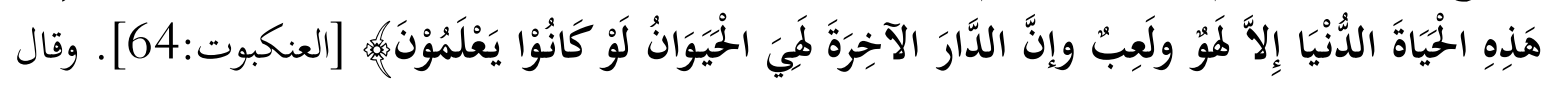

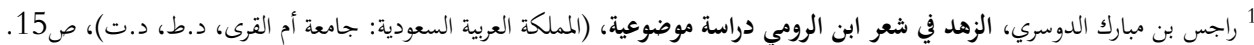

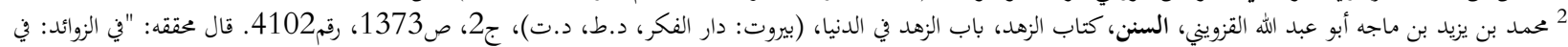

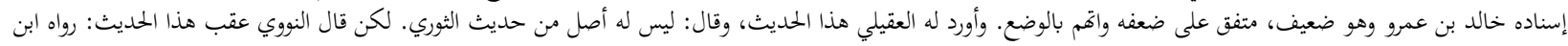




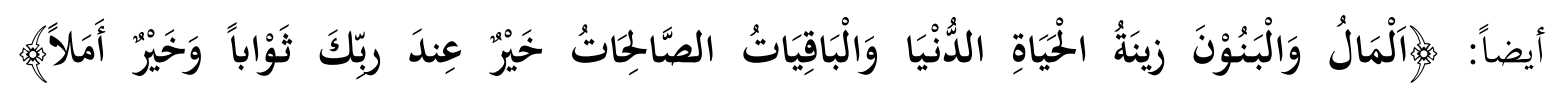
[الكهف:46:

لقد وصل دين الإسلام إلى الجزيرة الملايوية وما حولها من دول جنوب شرق آسيا منذ قرابة أربعمائة

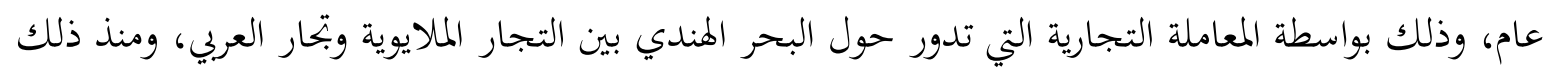

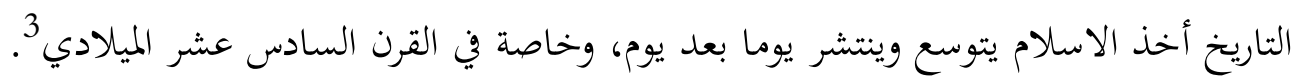

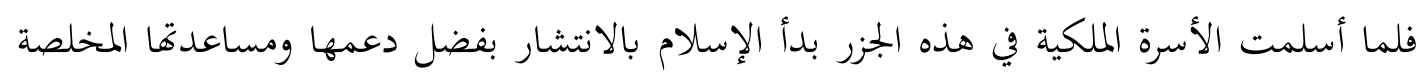
مادياً ومعنوياً، وأخذ بالانتشار أكثر فأكثر، حتى أصبح الإسلام ديناً لأغلب أهل هذه المنطقة، ونشط العلماء

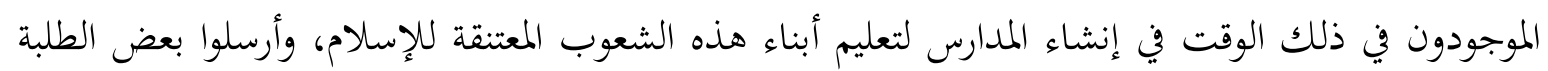
للاستزادة في العلم والمعرفة إلى البلاد العربية، ورجعوا إلى أوطاهم حاملين راية العلم والمعرفة، فازدادت هذه هذه إنهاء الشعوب علماً وكثر منها العلماء.

وقد اشتهر القرن الثاني عشر الهجري (القرن الثامن عشر الميلادي) بجهود العلماء في الجزيرة الملايوية حول جنوب شرق آسيا في نشر الإسلام و تأليف المؤلفات القيمة، وبرز منهم عالم من علماء ولاية فلمباني، وقام

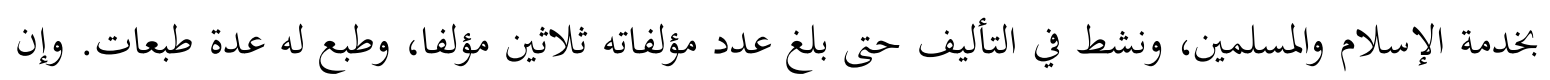
دل على شيء فإنه يدل على عظيم إخلاصه حيث حظي بتقدير الناس وإجلاهم إياه، وهذا هو الشيخ العلامة عبد الصمد الفلمبالي رحمه الله.

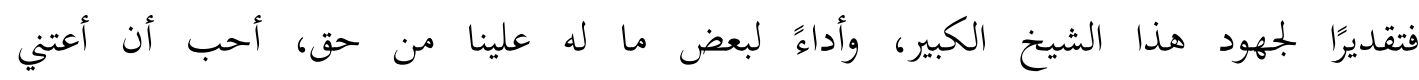
بدراسة علمية حول هذا الشيخ الجليل وبعض مؤلفاته حسب وسعي المتواضع من خلال هذا البحث، وهو

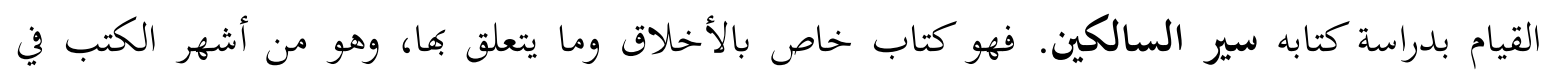

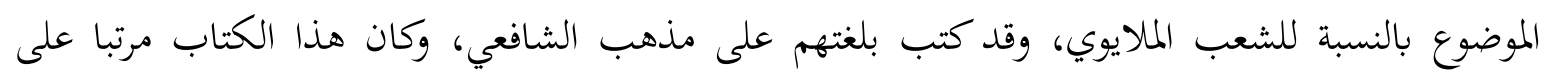

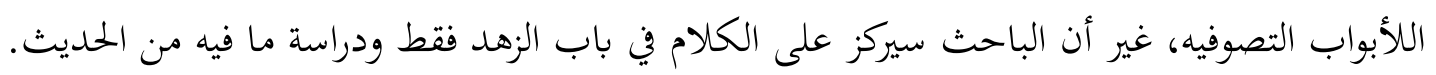

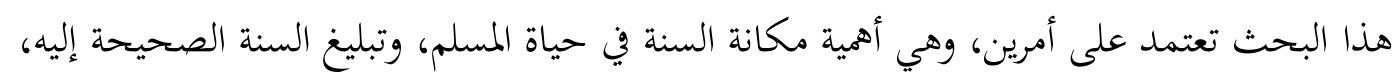
فالسنة تدير أحوال المسلمين في شؤون الحياة كلها، وكتاب سير السالكين للشيخ عبد الصمد الفلمباني كتاب الصياب قيم في باب الأخلاق، ولكن الذي يقرأه يحس في أول وهلة بأن الشيخ ذكر فيه أحاديث كثيرة وروايات عديدة

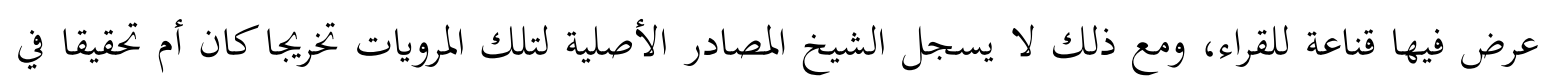

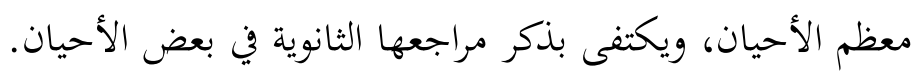

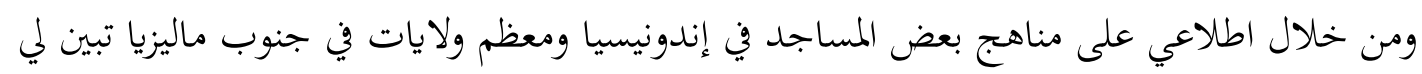
أن هذا الكتاب يكون مقرراً أساسياً في حلقاهم عن الأخلاق. ويتمسك المسلمون بهذا الكتاب تمسكا قوياً

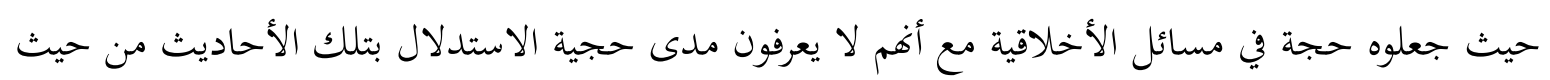
الصحة وعدمها.

Azyumardi Azra, The Origin of Islamic Reformism in Southeast Asia Network of MalayIndonesian and Middle Eastern Ulama in The Seventeenth and Eighteenth Centuries, Production Sdn Bhd 2004. 
وكذلك مفهوم خاطئ عن الزهد، والبعض يفهم الزهد في الدنيا أنه تحريم الطيبات وتضييع الأموال، ولبس المرقع من الثياب، ولجلوس في البيوت وانتظار الصدقات، ورفض المال وأن تكون فقيراً، والعالة على الناس، وكون اليد السفلى، هذا خطأ. وليس المراد من الزهد رفض الدنيا من الملك والرياسة والوزارة وعدم المشاركة في الحياة

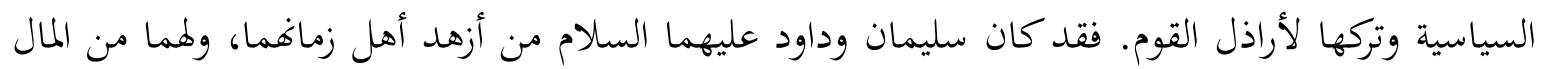
والملك والنساء.

\section{II ترجمة الشيخ عبد الصمد الفلمباني . II \\ السمه وولادته ونسبه}

وهو العارف بالله الشيخ المجاهد الصوين عبد الصمد الفلمباني بن الشيخ عبد الجليل بن الشيخ عبد الوهب بن الشيخ أحمد المهدي الشافعي المذهب. وكان الشيخ رحمه الله يعد من أحد أبرز علماء القرن الثامن عشر للهجرة، حيث إنه قام بنشر الإسلام في إندونيسا وغيرها من المناطق الجاوي.

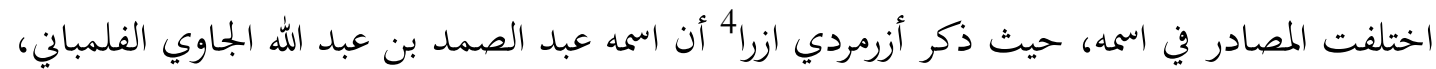
وقيل: السيد الشيخ عبد الصمد بن عبد الرحمن الجاوي، كما قال عبد الرزاق بن حسن بن إبراهيم البيطار الميداني الدمشقي، (المتوف وفيل: 1335هـ) في كتابه 5. وولد بفلمبان (Palembang) وهي مدينة كبيرة تقع بسومطرة جنوبية Selatan Sumatra) وكانت اشتهرت بالجاوي سنة 1116م/هن/ 1704هـ، وقيل: 1800/ 11112 وكانت فالمبان إحدى المراكز التي يزورها العرب كما كانت مركزا لدراسة العلوم الإسلامية ومسائلها. ولها دور هام في انتشار الإسلام. وأما والده الشيخ عبد الجليل بن الشيخ أحمد المهادين من اليمن، وهو عين من من أعيان

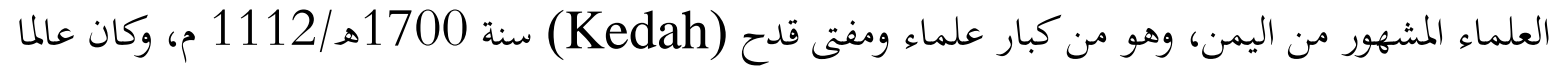

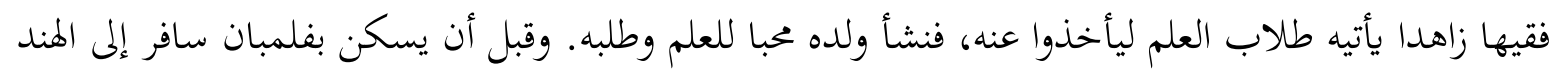
ونشأته ورحلاته وأخيرا في قدح بماليزيا.

نشأ الشيخ في بيئة صالحة وبيئة المجتمع الإسالام، وعاث في المجتمع الذي يحب التصوف. فعلمه

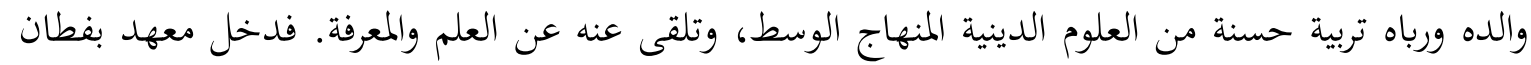

\footnotetext{
${ }^{4}$ Azyumardi Azra, Jaringan Ulama Timur Tengah dan Kepulauan Nusantara Abad 18 dan 19, (Jakarta: Mizan 2004) p.305.

5 عبد الرزاق بن حسن بن إبراهيم البيطار الميداني الدمشقي، حلية البشر في تاريخ القرن الثالث عشر، محقق محمد بهجة البيطار من أعضاء بجمع اللغة العربية، (بيروت: دار صادر د.ط،

${ }^{6}$ M.H. Dato Kerani Muhammad Arsyad, Silsilah Negri Kedah, (Kuala Lumpur, Dewan Bahasa dan Pustaka, 1968), p.123-126.
} 
(Fatani)

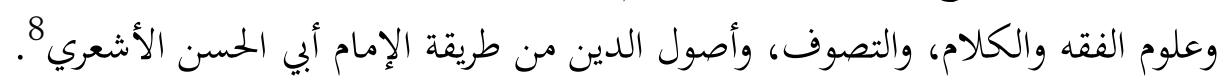

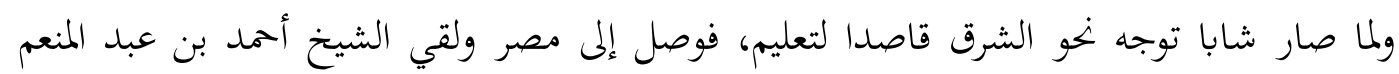
الدمنهوري وهو من علماء القاهرة، وخلال قيامه في القاهرة ألف كتاب "زهرة المريد من البيان كلمة التوحيد". تم رحل إلى الحرمين الشريفين فلقي عدة شيوخ منهم الشيخ محمد السمان المدني والشيخ عبد الرحمن بن عبد وهداء

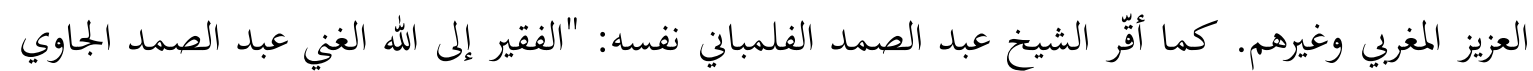
الفلمباني تلميذ القطب الرباني والعارف الصمداني سيدي الشيخ محمد السمان المدين نفعنا الله به والمسلمين 9. وقضى الشيخ عبد الصمد الفلمباني عمره في مكة المكرمة والمدينة المنورة، قال في النفس اليمني: "وفد

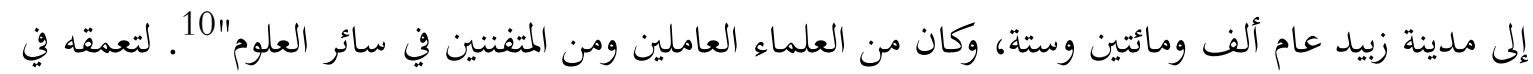

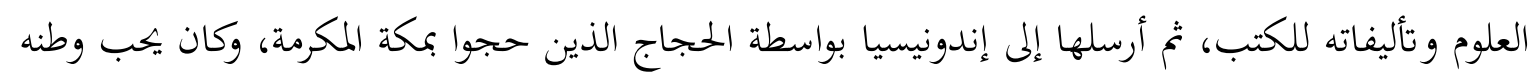
مما ظهر ذلك في كثير من مؤلفاته التى تحث على الشجاعة والمسائل الدينية والعقيدة وغير ذلك. وحماسته لدعوة الناس الجهاد لطرد المستعمرين من بلادهم.

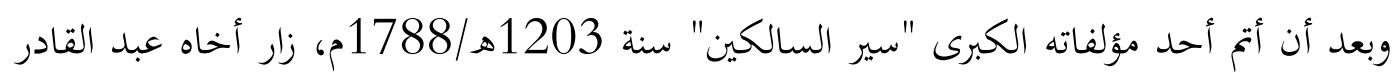
وهو مفتي بمدينة كوالا قدح (Kota Kuala Kedah) وكانت كوالا قدح مستعمرة تحت قوات سِيَام

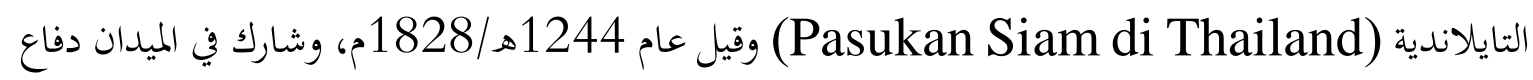
بلاده عن المستعمرين حتى قتل في ميدان الحرب ومات شهيدا بتايلاند.

$$
\text { شيوخه وتلاميذه }
$$

بدأ الشيخ عبد الصمد الفلمباني في تلقي العلوم مبكراً، وذكر أنه قام ببعض رحلاته العلمية في السنة الخامسة من عمره. فبدأ طلبه للعلم وهو صغير على يدي والده على طريقة التعلم في فلمبان. تم واصل تعليمه إلى فطاني. لقد استفاد الشيخ عبد الصمد الفلمباني من رحلاته استفادة جمة. حيث حصل حصل سماعه من شيوخ

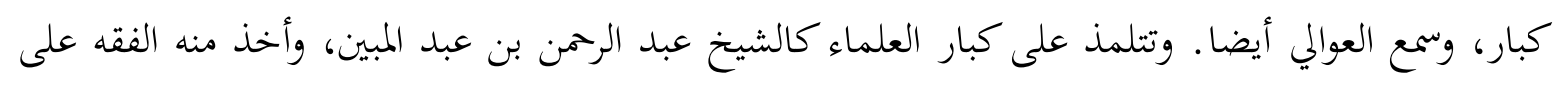
مذهب الامام الشافعي. وأخذ من الشيخ محمد بن سمان علم الكاملام على مذهب أبي الحسن الأشعري وأببي

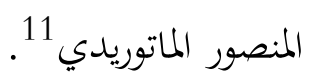

ثم رحل إلى مكة في سنة 1178هـ/1768م وأخذ منها العلم غير ما حصل، ولقي أصدقائه الذين

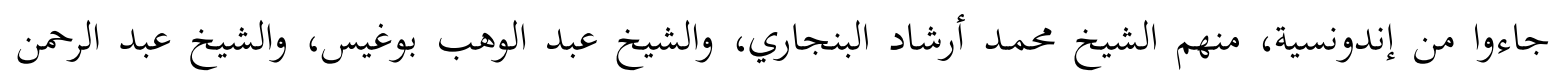
البتاوي، والشيخ داود الفطاني. والتقى بالعلماء والشيوخ فأخذ منهم العلوم وراسلهم. وأشهر شيوخه في مكة:

\footnotetext{
${ }^{7}$ Ensiklopedi Islam di Indonesia, Direktorat Jendral Pembinaan Kelembagaan Agama Islam Proyek Peningkatan Prasarana dan Sarana Perguruan Tinggi Agama Islam, (Jakarta: Institut Agama Islam Negri 1993), p.31.

${ }^{8} \mathrm{Hj}$. W. Muh. Shaghir Abdullah, Syeikh Abdush Shamad Al-Palimbani Ulama Shufi dan Jihad Melayu, (Kuala Lumpur: Dewan Bahasa dan Pustaka, 1996), p.9.

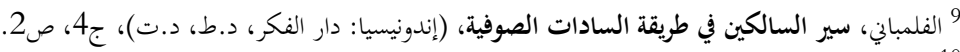

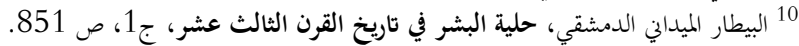

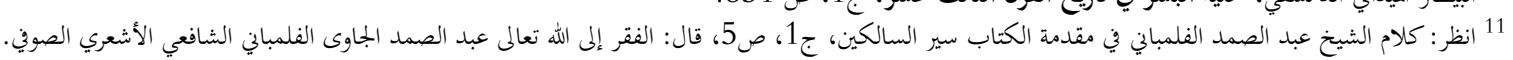

TAHDIS Volume 11 Nomor 2 Tahun 2020 
1. الشيخ عطاء المصري، ولد بمصر وبها نشأ وقرأ في الفنون على بعض أهل عصره وحفظ الملحة والالفية

$$
\text { وغيرها واشتهر بفن الأدب عاء } 12 .
$$

2. والشيخ محمود الكردي، وكان مشهور البركة يعتقده الخاص والعام كثير الرؤية لرسول ومن كراماته أنه متى

$$
\text { أراد رؤية النبي صلى الله عليه وسلم رآه } 13 .
$$

3. الشيخ عبد المنعم، أجازه أبو الأحسان بن ناصر وغيره، توفي سنة 1153 115، ودفن بمشهد أسلافه عند

$$
\text { ضريح الإمام الشافعي } 14 .
$$

4. الشيخ إبراهم الرائس، وهو الإمام الفصيح المعتقد الشيخ إبراهيم بن محمد بن عبد السلام الرئيس الزمزمي

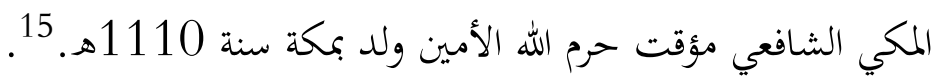

5. الشيخ محمد الجوهري، وهو الإمام الفقيه المحدث الأصولي المتكلم شيخ الإسلام وعمدة الأنام. وولد بمصر

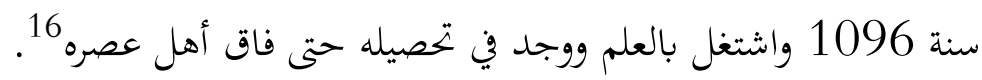

مؤلغاته

ألف الشيخ عبد الصمد الفلمباني مؤلفات كثيرة في تحصيل العلوم من الكلام والفلسفة، والعقيدة والتوحيد، وعلوم التصوف، حتى بلغ ذروتما وحرّر فنوها في وقت يسير فانتفع به العباد والبلاد، فصار موسوعةً

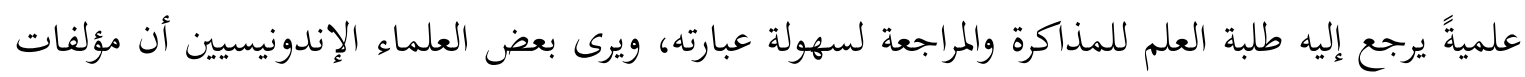

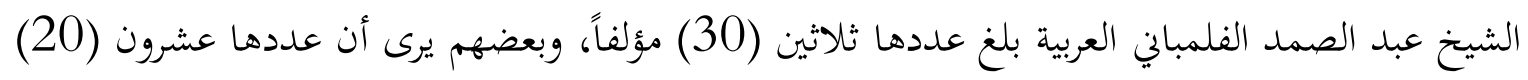

اشتهر الشيخ عبد الصمد الفلمباني بكثرة الكتب، منها: 1. هداية السالكين في سلوك مسلك المتقين، وهي ترجمة وشرح بالملاوية لكتاب بداية الهداية للغزالي ونسخته في المكتبة البريطانية. تم هذا الكتاب في محرم 1192هـ في مكة المكرمة كما جاء في آخر المخطوطة، ولعلها أقدم النسخة الخطية.

2. سير السالكين إلى عبادة رب العالمين شرح لباب إحياء علوم الدين للإمام الغزالي، بعد كتابة هداية

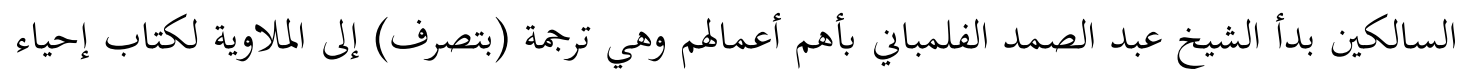

$$
\text { علوم الدين للإمام الغزالي. }
$$

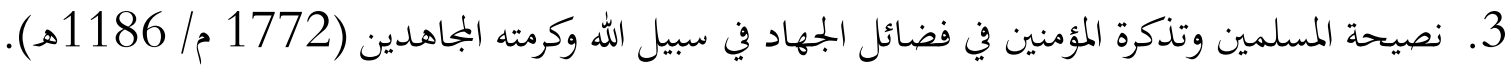
هذه الرسالة باللغة العربية في فضل الجهاد وكتبها الفلمباني لحث أهل بلاده إندونيسيا على مقوامة الاحتلال الهولندي. هذه الرسالة لم تطبع حسب علمي ونسخة موجودة في مكتبة إندونيسيا الوطنية في جاكرتا. 17

$$
\begin{aligned}
& 12 \text { الجبرتي، تاريخ عجائب الآثار في التراجم والأخبار، (بيروت: دار الجيل، د.ط، د.ت)، ج2، ص89. }
\end{aligned}
$$

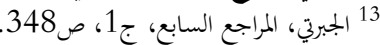

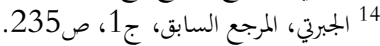

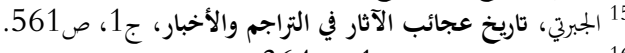

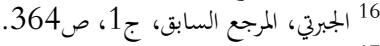

$$
\begin{aligned}
& 17 \text { عمر رضا كحالة، معجم المؤلفين، (بيروت: مؤسسة الرسالة، د.ط، د.ت)، ج2، ص153. }
\end{aligned}
$$


4. زهرة المريد في بيان كلمة التوحيد مختصر علم التوحيد، علمه الشيخ أحمد بن عبد المنعم الدمنهوري الأزهري

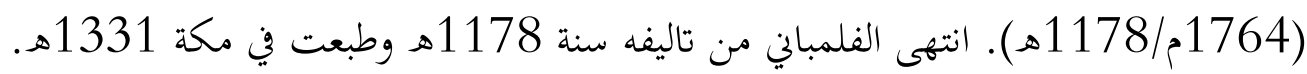
5. تحفة الراغبين في بيان حقيقة إيمان المؤمنين وما يفسده في ردة المريدين، مطبوع ونسخة مخطوطة منها منه في في

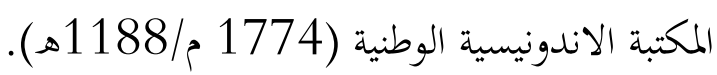

ثناء العلماء عليه

فقد بينها أقلام بعض العلماء والباحثين، والنظر فيها من عدة جوانب، منها: كثرة تصانيفه وطلابه ودوره في نشر العلوم الشرعية: 1. وفي كتاب: حلية البشر في تاريخ القرن الثالث عشر للشيخ عبد الرزاق بن حسن بن إبراهيم البيطار الميداني

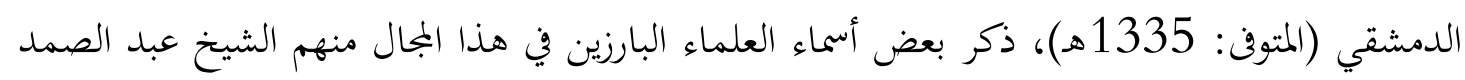
الفلمباني، قال المؤلف: "أوحد العلماء مفرد الفضلاء، الولي التقي والعارف النقي" "18.

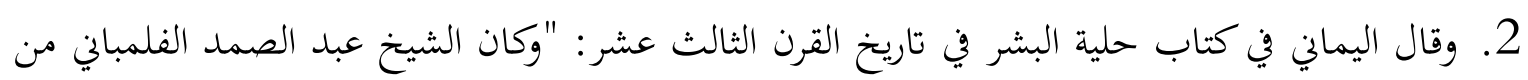

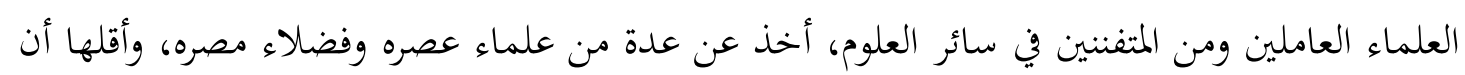
ينكشف للمشتغل به والمقبل عليه عيوب نفسه ونقصها وتقصيرها، ويكون ذلك بعد توفيق الله سبحانه عاصماً له عن الغرور. أنه قد كثر من زمن الأولين الاعتناء والمطالعة في كتاب إحياء" 19.

وفاته

لقد عاش الشيخ عبد الصمد الفلمباني في تايلند، وبعد حياة مليئة بالنفع والانتفاع والعلم والتعليم

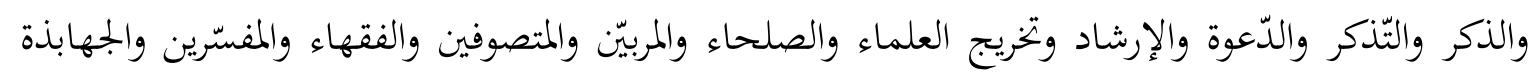

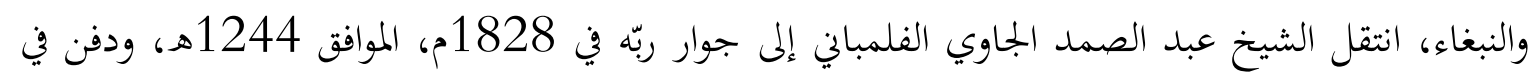
مقبرة تايلند بين سيكوم وجيناك في ولاية تيب فطاني شمال. رحمه الله تعالى وأسكنه أعلى جنته ونفعنا بعلومه النها وبركاته 20.

\section{التعريف بكتاب سير السالكين ومنهجه فيه .III}

واشتهر الكتاب باسم "سير السالكين" كما جاء في النسخه المطبوعة، ولكن الاسم الصحيح للكتاب "سير السالكين إلى عبادة رب العالمين". يقع هذا الكتب في أربعة مجلدات كبار، وهو مطبوع ومتداول بين أهل 2004) p.305. 
قد انتشر هذا الكتاب انتشار واسعا في جنوب شرق آسيا. وهو مرتب على الكتب والأبواب الأخلاقية ومحتوى على الأحاديث المرفوعة والأثار الموقوفة والمقطوعة. هو أهم وأشهر كتب الشيخ عبد الصمد الفلمباني وأكثرها انتشارا، ويستفيد منه العديد من العلماء والخطباء منذ تأليفه إلى يومنا هذا.

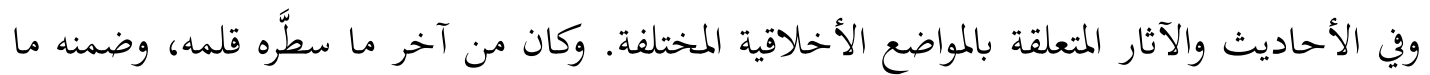
انتهى إليه علمه وفهمه، فاستعرض فيه مسائل العقيدة على طريقة المتكلّمين "الأشعرية".

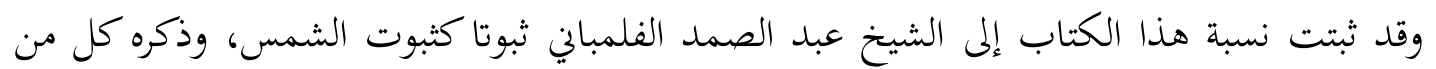
ترجم للشيخ، وهو مذكور في كتب التراجم والتاريخ، حتى يلقب بصاحب سير السالكين لتمييزه بينه وبين آخرين.

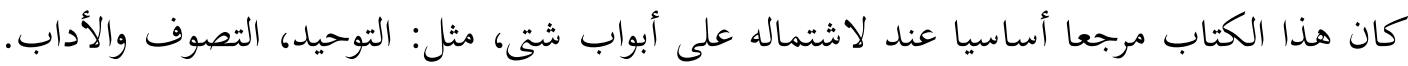
وقد طبع طبعات كثيرة، ووجد الباحث أن آخر التأليف هذا الكتاب سنة 1203هـ/1789م حسب طبن طبعة مطبعة المرية الكينة بطائف، ثم طبع في سنة 1318ه، وانتشر في الهند دول جنوب شرق وق آسيا مثل مليزيا، تايلاند، سنغافورة، الفلبين، بورما، وإندونسيا.

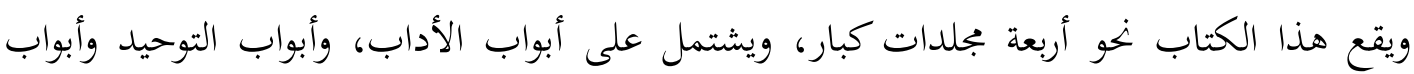
التصوف. الجزء الأول يبحث عن أصول الدين، كتب في سنة 1193هـ إلى 1194هـ في مكة. كما قال الشيخ عبد الصمد الفلمباني نفسه: "لماكانت سنة ألف ومائة وثلاث وتسعين من هجرة النبي صلى الله عليه وسلم، ألهم الله تعالى في قلبي أن أترجم كتاب إمام الغزالي رحمه الله تعالى المسمى بلباب إحياء علوم الدين الجامع بين الشريعة والطريقة، والمتضمن فيه علوم أصول الدين والفقه والتصوف النافعة، بالكاملام الجاوي مع زيادة فوائد نفيسة

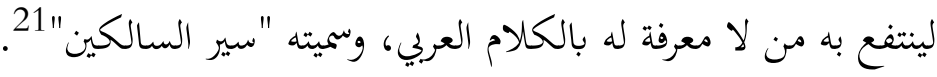

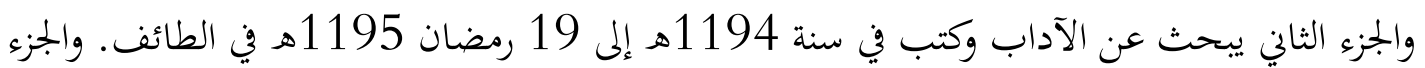
الثالث يبحث عن بيان حقيقة حسن الخلق وسوء الخلق، وكتب في سنة 1195هـ إلى 19 سفر 197 1197هـ في

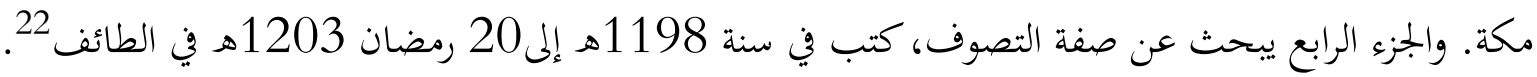

$$
\text { منهجه في كتابة الحلديث }
$$

أورد في كتابه الأحاديث المرفوعة على النبي صلى الله عليه وسلم والآثار الموقوفة على الصحابة والمقطوعة على التابعين ومن بعدهم وذكر من خلالما قول الفقهاء في فتاوى الأحكام. ورتبها على الكتب والأبواب. أما

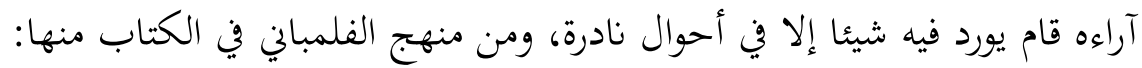

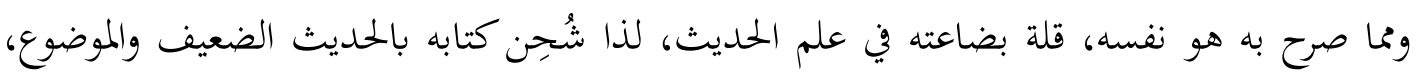
لكن في المقدمة حصل التكلف في حمل كلامه السابق على التواضع، وعلى أن الصحيح أضعاف الضعيف، وأنه تسربت بعض الأحاديث الضعيفة وقليل دوفا في فضائل الأعمال. 
ويكفي في رد هذا الكلام أن يطالعوا ما وجدتُ من الأحاديث التي لم يجد لها إسنادا فقط دون ذكر الموضوع أو الضعيف، ثم ما ذكرته الباحثين في دراستهم أن خاتمة أمره كانت بإقباله على الحلديث النبوي كالبخاري ومسلم وغيرهما.

وأما الأحاديث الواردة في هذا الكتاب فلم يسندها المؤلف إلى من رواها من أئمة الحلديث واكتفى بذكر أطرافها فقط ولم يتطرق إلى ذكر درجاةقا من حيث الصحة أو الضعف، وكان منهجه في ذلك كمنهج الفقهاء في كتبهم.

\section{IV

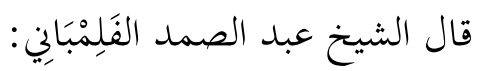

1. قال النبي صلى الله عليه وسلم: 》إذا رأيتم العبد قد أوتي صمتا وزهدا في الدنيا فاقتربوا منه فأنه يلقي الحكمة《.

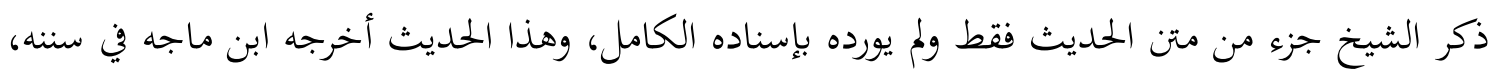

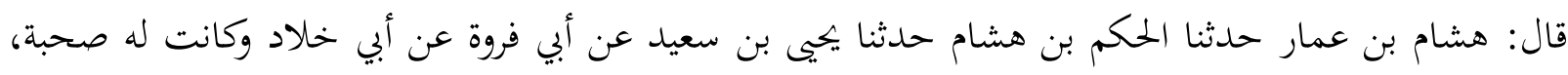
قال: قال رسول الله صلى الله عليه وسلم: اإذا رأيتم الرجل قد أعطي زهدا في الدنيا، وقلة منطق، فاقتربوا منه، فئإنه يلقي الحكمة《؛ 23. دراسة السند السفاس

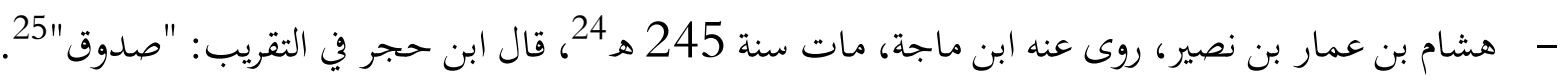

$$
\text { وقال الذهبي في الكاشف: "الحافظ"26. }
$$

- - الحكم بن هشام بن عبد الرحم، روى عنه هشام بن عمار، مات سنة 238هـ 27، قال ابن حجر في التقريب:

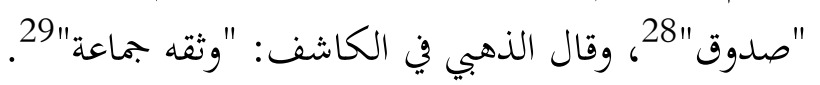

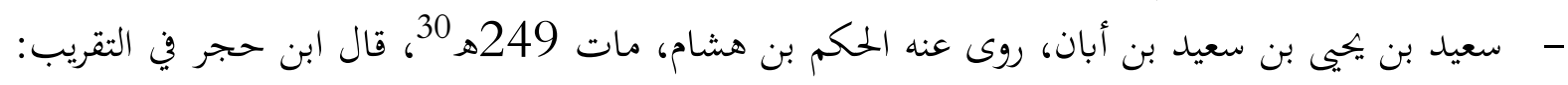

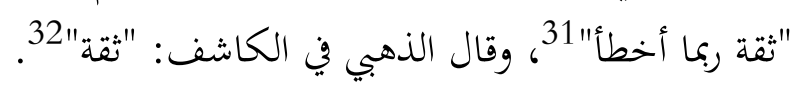

23 محمد بن يزيد أبو عبد الله القزويني، سنن ابن ماجه، معقق محمد فؤاد عبد الباقي، كتاب الزهد، باب الزهد في الدنيا، رقم الحديث 4101، (بيروت: دار الفكر، د.ط، د.ت)،ج3، ص ص 1373

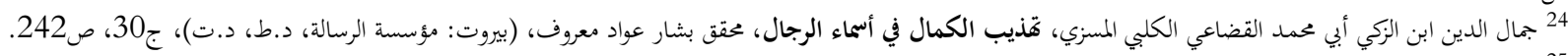

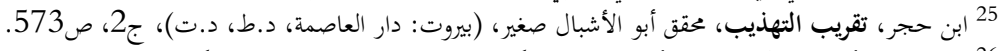

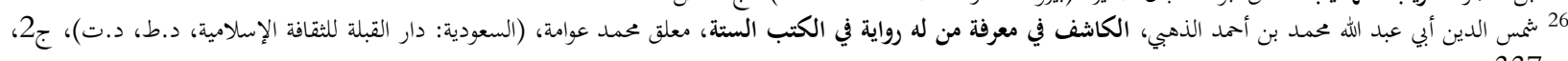

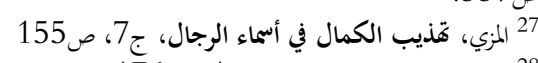

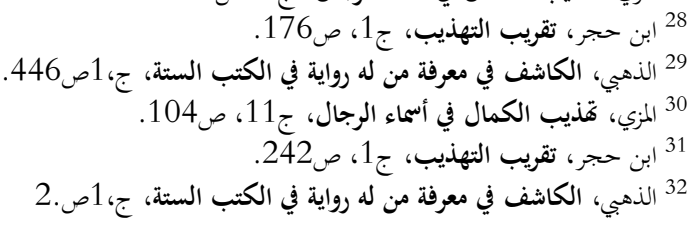


- يزيد بن سنان بن يزيد التميمي، روى عنه يجيى بن سعيد، مات سنة 155هـ، 33 قال ابن حجر في التقريب:

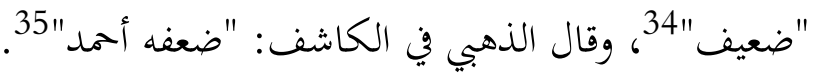

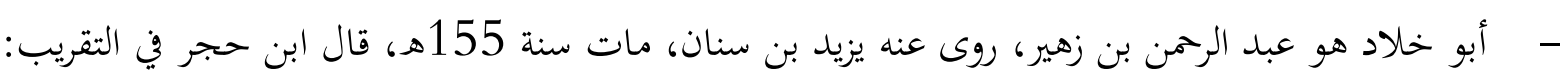

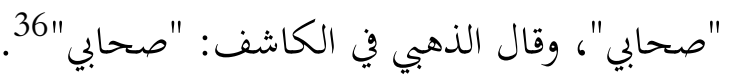

أخرجه ابن ماجه عن أبي خلاد عن أبي فروة مثله 37، والطبراني عن أبي خلاد عن أبي فروة مثله 38، وأبو نعيم فن الحلية

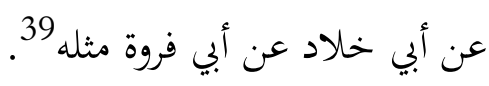

شواهده

حديث أبو هريرة، أخرجه البيهقي في الشعب قال: "أخبرنا أبو عبد الله الحافظ أنا جعفر أحمد بن عبيد الحافظ بكمدان

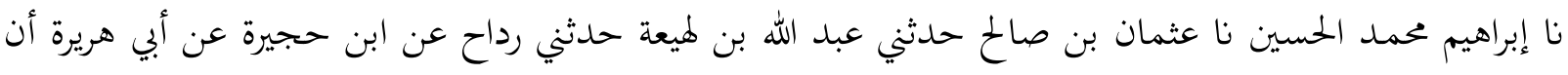
رسول الله صلى الله عليه وسلم قال مثله"40.

\section{حكمه}

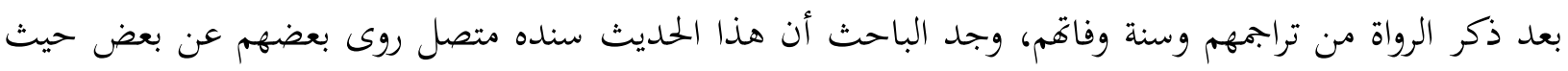

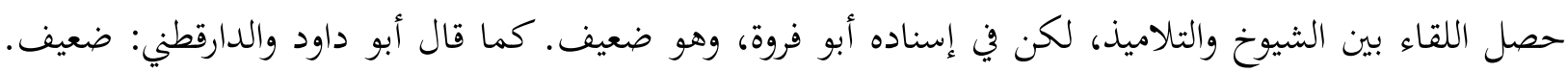

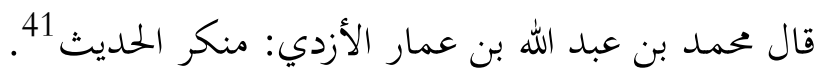
من زهد في الدنيا فهو منور القلب، مشروح الصدر.

2. قال صلى الله عليه وسلم: 》ازهد في الدنيا يجبك الله وازهد فيما في أيدي الناس يجبك الناس《.

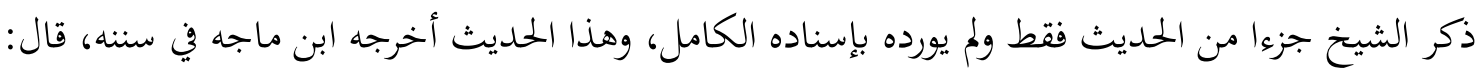

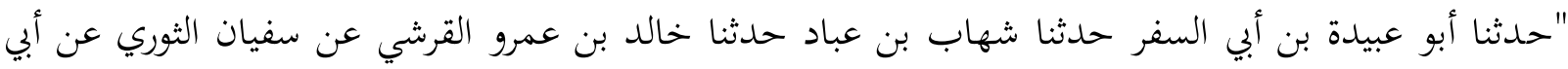

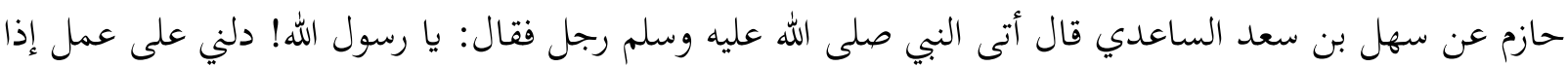

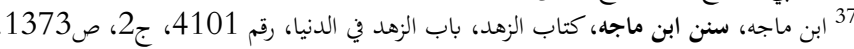

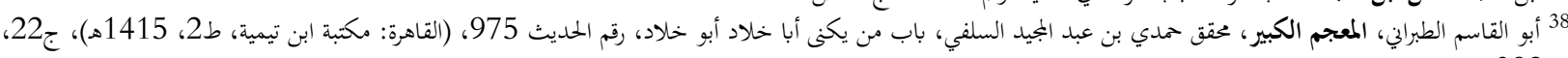

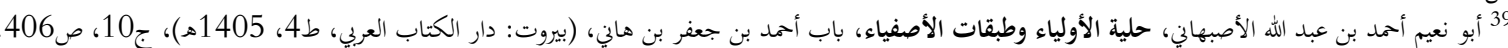

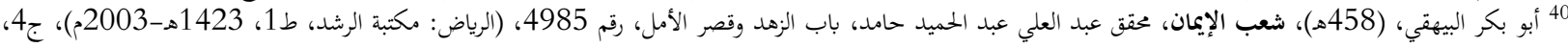

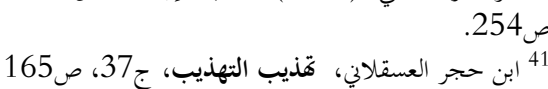


أنا عملته أحبني الله وأحبني الناس. فقال رسول الله صلى الله عليه وسلم: اازهد في الدنيا يهبك الله وازهد فيما في

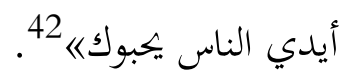

دراسة السند

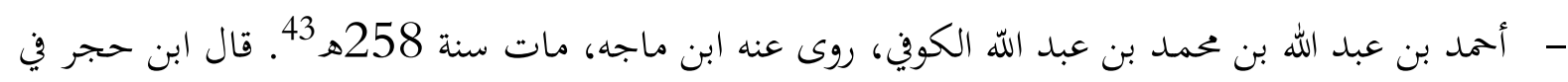

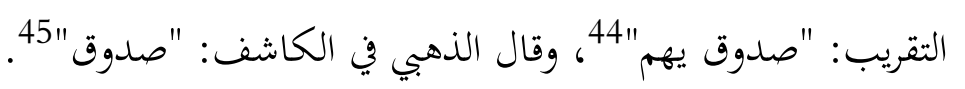

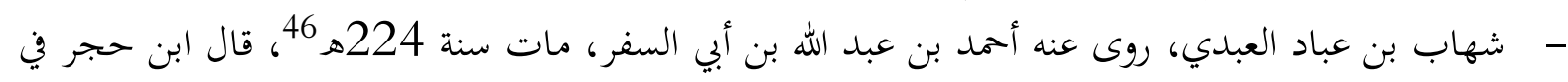

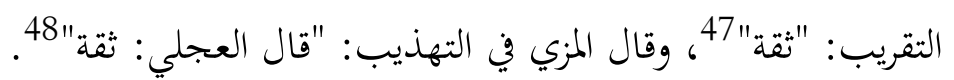

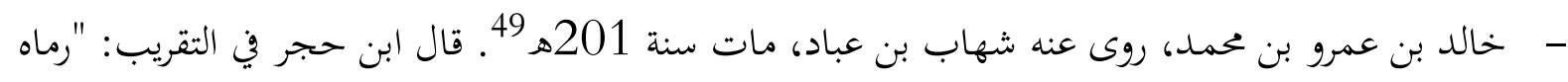

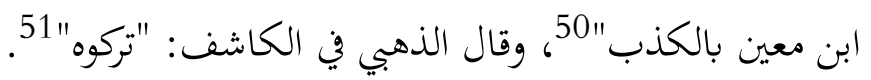

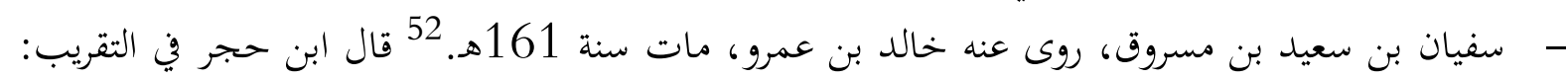

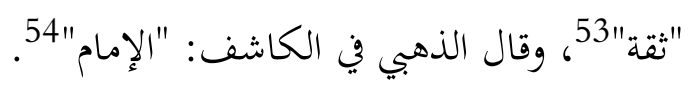

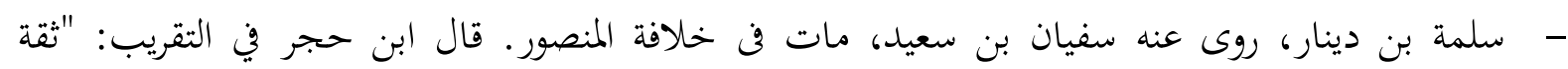

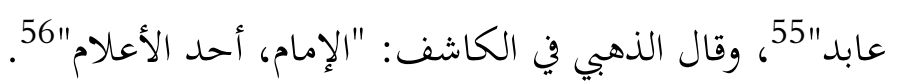

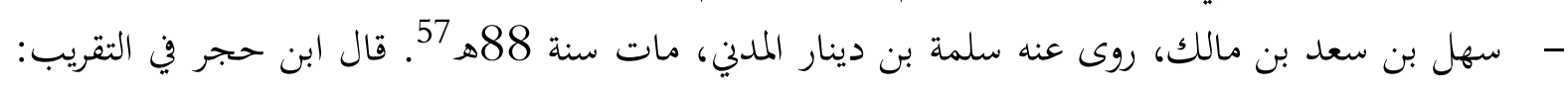

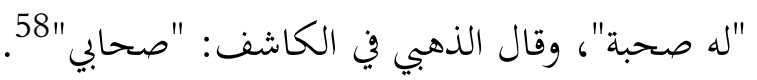

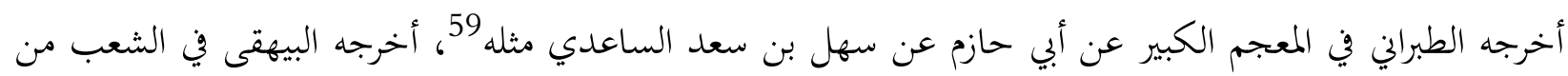

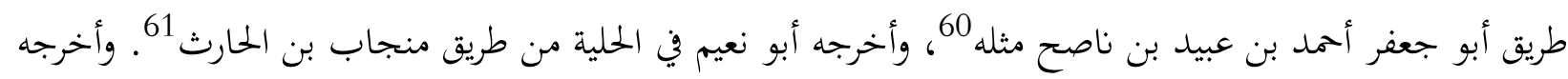
حاكم في المستدرك عن خالد بن عمرو القرشي مثله كئ.

$$
\begin{aligned}
& 42 \text { ابن ماجه، سنن ابن ماجه، كتاب الزهد، باب الزهد في الدنيا، رقم الحديث 1372، 1367، ج2، ص1373. }
\end{aligned}
$$

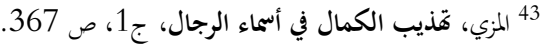

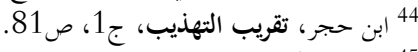

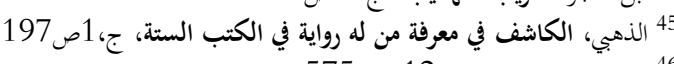

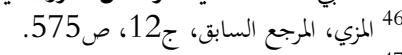

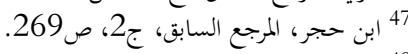

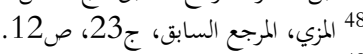

$$
\begin{aligned}
& \text { } 49 \text { الذببي، تاريخ الإسلام ووفيات المشاهير وَالأعلام، عحق بشار عوّاد معروف، (السعودية: دار القبلة للثقافة الإسلامية، د.ط، د.ت)، ج5، ص66. } \\
& 50
\end{aligned}
$$

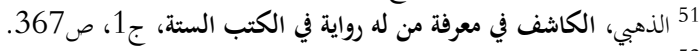

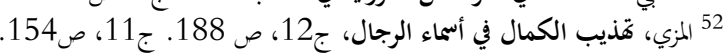

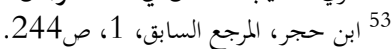

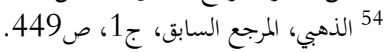

$$
\begin{aligned}
& 55 \text { ابن حجر، المرجع السابق، ج1، صل، ص247. }
\end{aligned}
$$

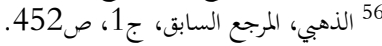

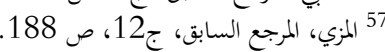

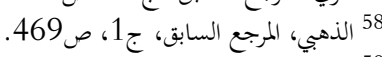

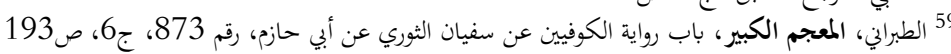

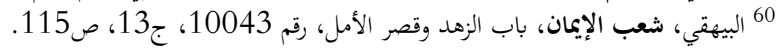

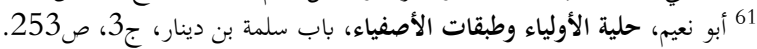

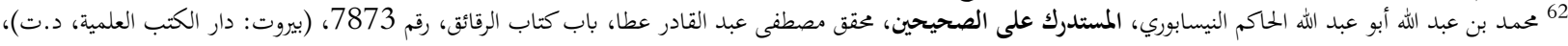


حديث أنس بن مالك، أخرجه أبو نعيم في الحلية، قال أبو أحمد إبراهيم ابن محمد بن أحمد ثنا أبو حفص عمرو بن

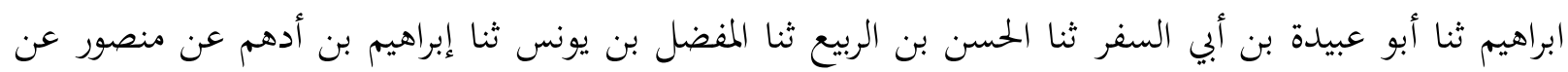

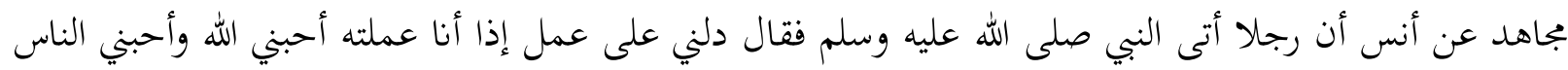

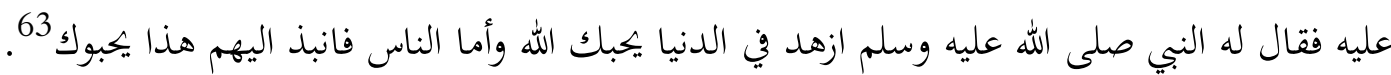
حكمd وقد حسن بعض مشايخنا إسناده، وفيه بُعد لأنه من رواية خالد بن عمرو، وخالد هذا قد ترك، واتم ولم أر من ثقه.

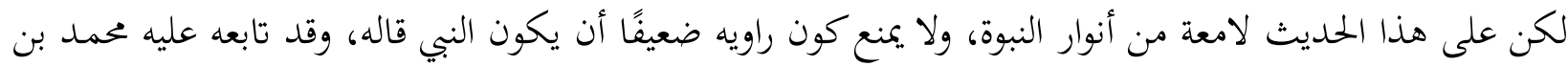

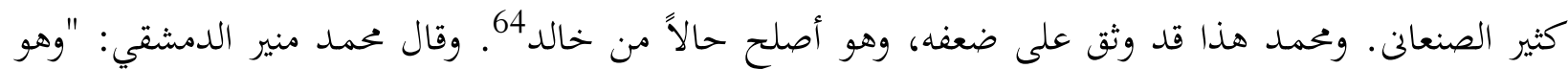

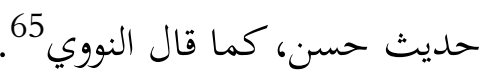
من فوائده الزهد في الدنيا من أسباب محبة الله تعالى، ومن أسباب نيل محبة الناس الزهد فيما في أيديهم 66.

3. ق قال صلى الله عليه وسلم: 》امن أصبح وهمه الدنيا شتت الله عليه أمره وفرق عليه ضيعته وجعل فقره بين عينيه ولم

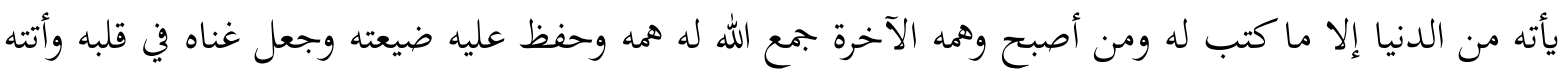

$$
\text { الدنيا وهي راغمة/《. }
$$

ذكر الشيخ من متن الحديث فقط ولم يورده بإسناده الكامل، وهذا الحمديث أخرجه الترمذي في سننه، قال:

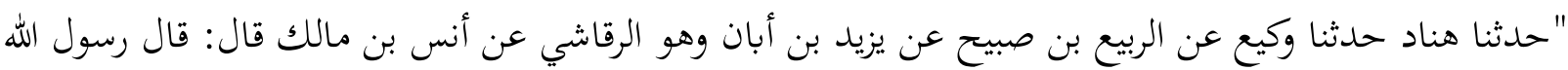

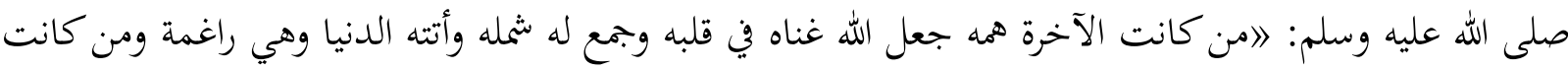

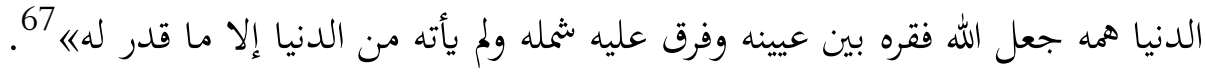

- هناد بن السري الدارمي، روى عنه الترمذي، مات سنة 234هـ 68. قال ابن حجر في التقريب: "ثقة"69،

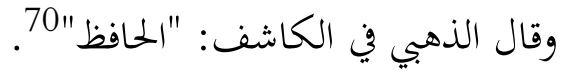

- ـوكيع بن الجراح الكوفي، روى عنه هناد بن السري، مات سنة 196هـ أو 197هـ 71. قال ابن حجر في التقريب:

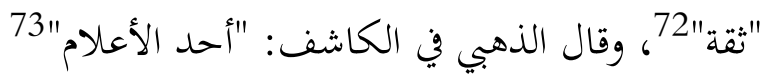

\footnotetext{
63 أبو نعيم، حلية الأولياء وطبقات الأصفياء، ج8، صب صباء.

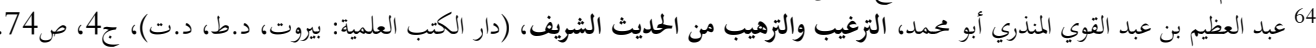

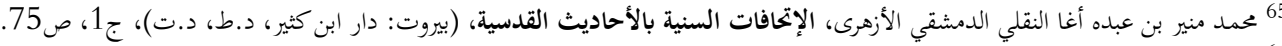

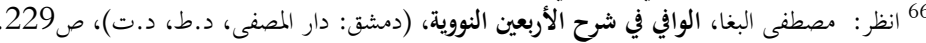

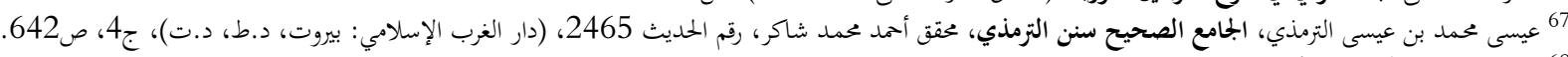

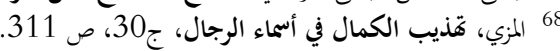

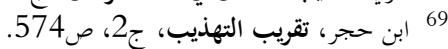

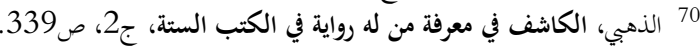

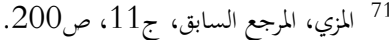

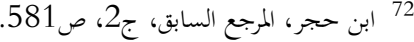
73 الذهبي، المرجع السابق، ج2، ص350.
} 
- - الربيع بن صبيح البصري، روى عنه وكيع بن الجراح، مات سنة 160هـ 74، قال ابن حجر في التقريب: "صدوق

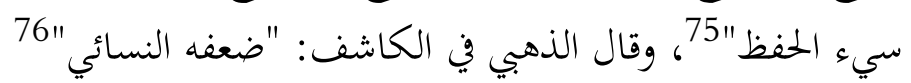

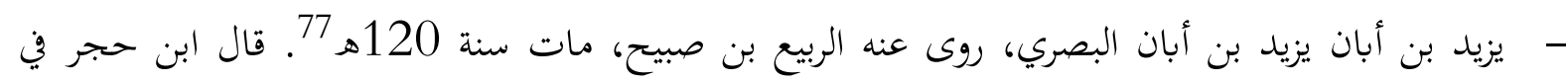

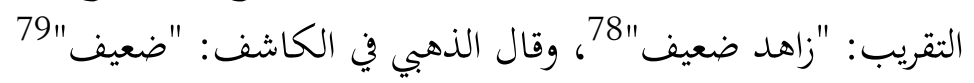
- أنس بن مالك بن النضر، روى عنه يزيد بن أبان الرقاشى، مات سنة 92هـ و قيل 93هـ. قال ابن حجر في وفيق

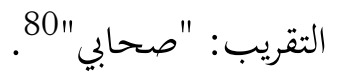

تخريجه أخرجه البزار عن إسماعيل بن مسلم عن الحسن مثله 81، أخرجه أبو نعيم عن أحمد بن علي الخزاعي عن محمد بن

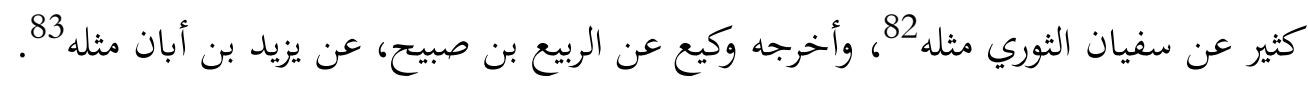

شواهده

حديث زيد بن ثابت، أخرجه ابن ماجه في سننه قال: "محمد بن بشار ثنا محمد بن جعفر ثنا شعبة عن عمر سليمان

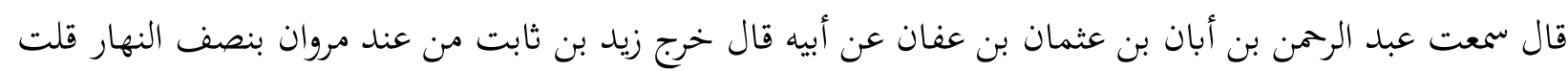

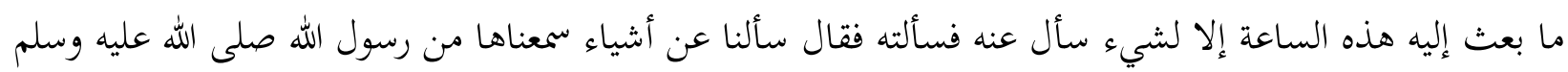

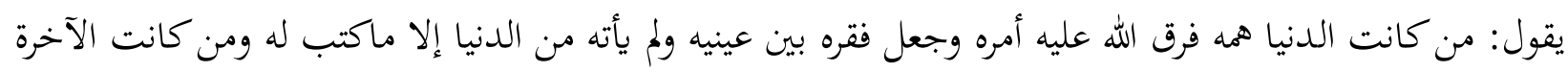

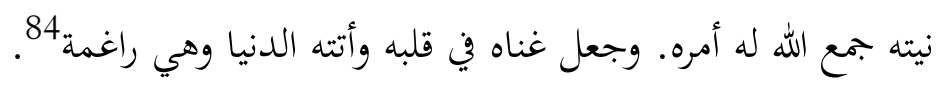
حكمه

والحديث لم يجكم عليه الترمذي بشيء من الصحة والضعف، وفي سنده يزيد الرقاشي وهو ضعيف على ما قال

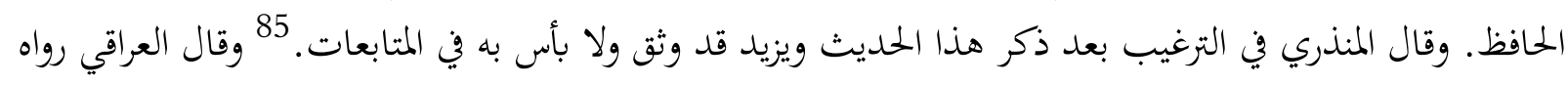
ابن ماجه من حديث زيد بن ثابت بسند جيد.

من فوائده

من أعرض عن الدّنيا، وأقبل على الآخرة، رزق الفراغ والتنعم وجمع الشمل، وأتته الرفق فيها والمهنأ منها فيكون له

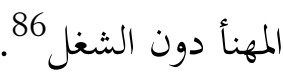
4. قال النبي صلى الله عليه وسلم: 》امن أراد أن يؤتيه الله علما بغير تعلم وهدى بغير هداية فليزهد في الدنيا).

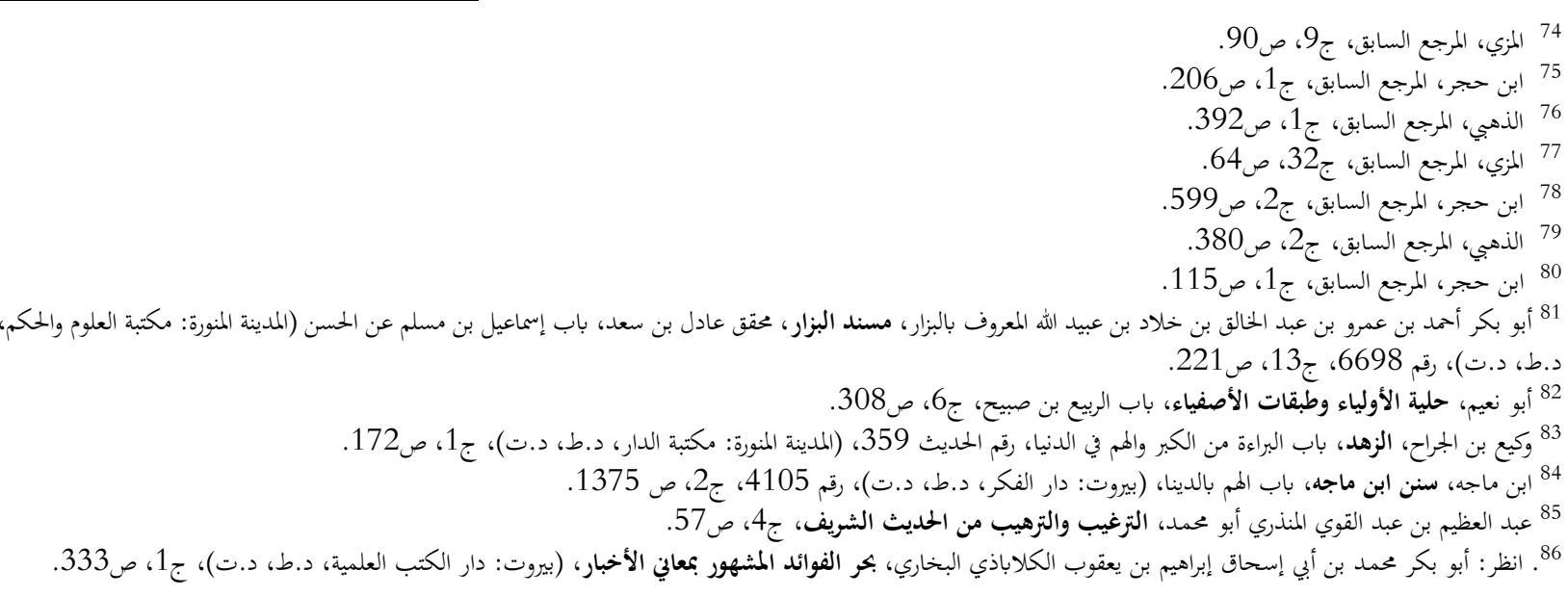


ذكر الشيخ من متن الحديث فقط ولم يورده بإسناده الكامل، وهذا الحلديث أخرجه البيهقي في الشعب، قال: "حدثني محمد بن علي بن شقيق ثنا إبراهيم بن الأشعث أنا الفضيل بن عياض عن عمران بن حسان عن الحسن قال:

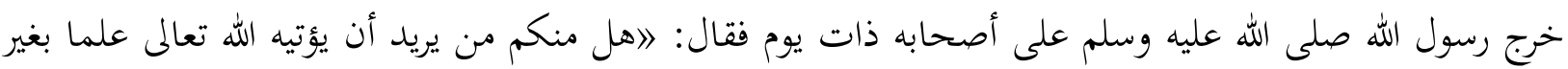

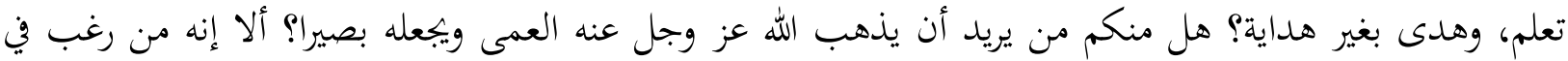

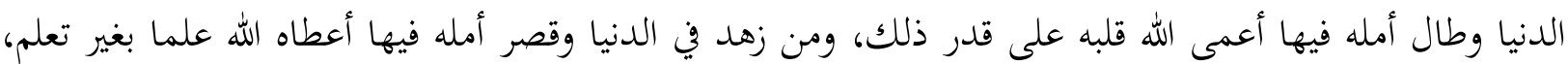
وهدى بغير هداية《ان. دراسة السند

- محمد بن علي بن الحسن بن شقيق، روى عنه عبد الله بن محمد بن عبيد بن سفيان بن قيس، مات سنة

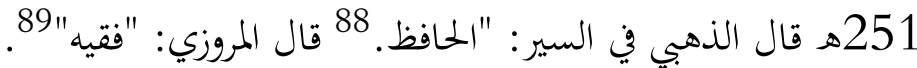

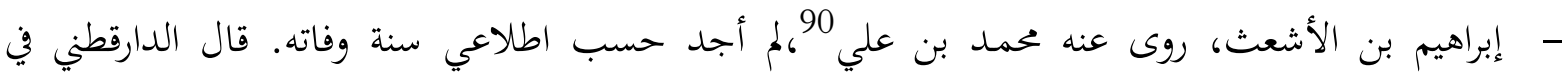

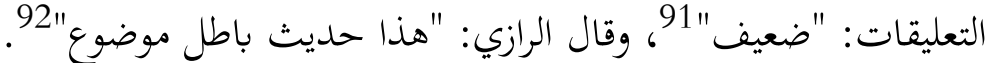

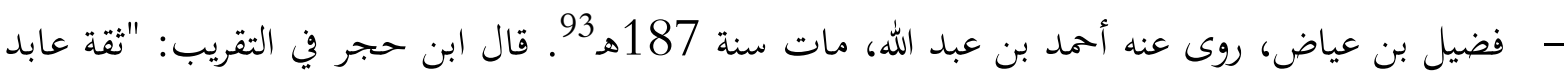

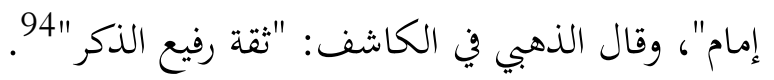
- عمران بن حسان، روى عنه فضيل بن عياض، لم أجد حسب اطلاعي سنة وفاته. قال ابن حجر في للسان الميزان: ضعيف 95 - الحسن بن الحسن بن يسار أبو عبد الله البصري، روى عنه عمران بن حسان، مات سنة 188هـ 96، قال ابن حجر في التقريب: "ثقة"97، وقال الذهبي في الكاشف الشف: "ثقة"

أخرجه الشجري الجرجاني عن عبد الله بن محمد بن العباس عن سلمة بن شبيب عن سهل بن عاصم عن إبراهيم بن

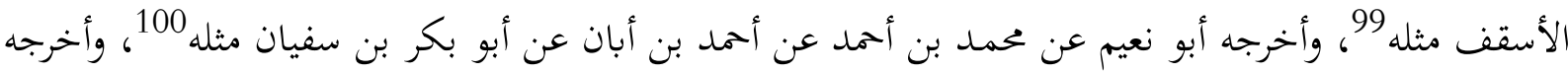
أبي الدنيا مثله 101.

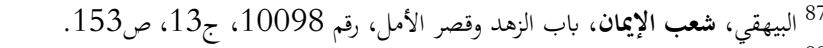

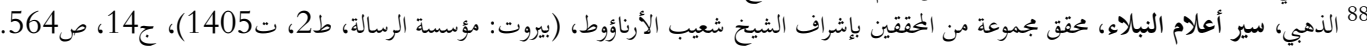

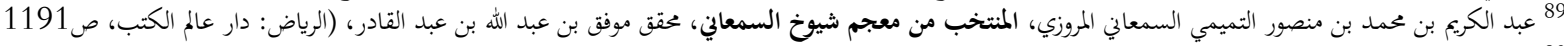

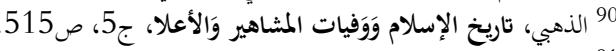

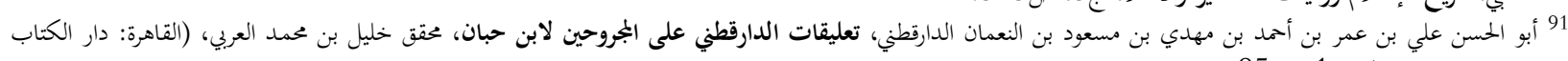

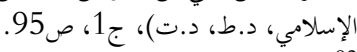

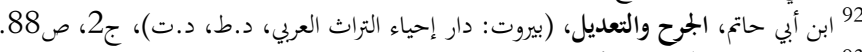

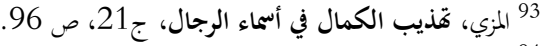

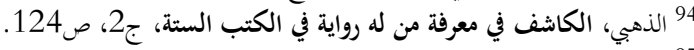

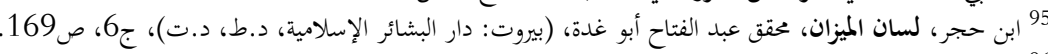

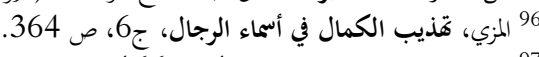

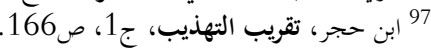

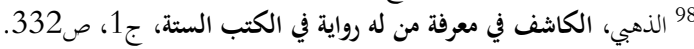

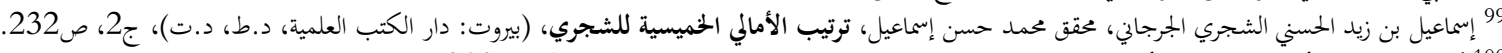

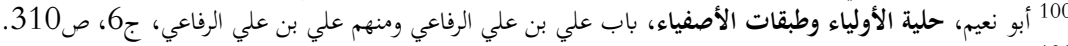

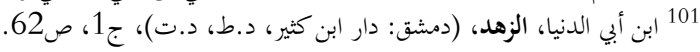


حديث عبد الله بن عباس، أخرجه الأصبهاني في الأخبار، قال حدثنا أبو سعيد الحسين بن محمد بن علي ثنا أحمد بن محمد بن مسعدة الفزاري الأصبهاني ببغداد، ثنا يوسف بن حمدان القزويني، ثنا عبد الله بن زياد بقزوين ثنا إسماعيل بن عياث عن إسماعيل بن عبد الله اللخمي عن مهاجر عن عطاء عن ابن عباس قال: قال رسول الله صلى الله عليه

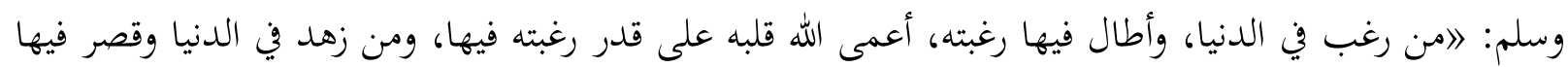

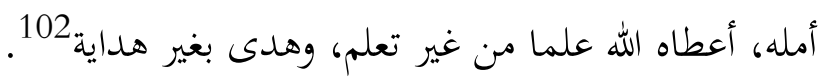

حكمه

سنده ضعيف، فيه إبراهيم بن الأشعث، وإبراهيم روايه عن فضيل ضعيف 103، وتكلف الروايه فيأتي بالأباطيل 104. من فوائده أن من عمل بما يعلمه من واجبات الشرع ومندوباته مثل الزهد في الدنيا، واجتناب مكروهاته ومحرماته مثل حب ذون

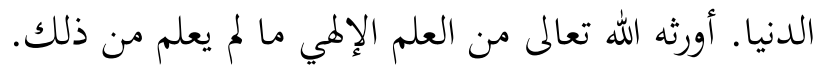

5. قال صلى الله عليه وسلم: لما قال له حارثة: اأنا مؤمن حقا، فقال: وما حقيقة إيمانك؟ قال: عزفت نفسي عن الدنيا فاستوى عندي حجرها وذهبها، وكأين بالجنة والنار، وكأني بعرش ربي بارزا، فقال صلى الله عليه وسلم العرفت فالزم عبد نور الله قلبه بالإيمانها. ذكر الشيخ جزءا من الحديث فقط ولم يورده بإسناده الكامل، وهذا الحديث أخرجه الطبراني في المعجم، قال: "حدثنا محمد بن عبد الله الحضرمي حدثنا أبو كريب ثنا زيد بن الحباب ثنا ابن لهيعة عن خالد بن يزيد عن سعيد بن أبي هلال عن محمد بن أبي الجهم عن الحارث بن مالك الأنصاري أنه مر برسول الله صلى الله عليه وسلم فقال له:

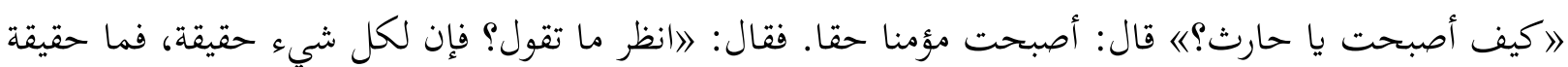
إيمانك؟《 فقال: قد عزفت نفسي عن الدنيا، وأسهرت لذلك ليلي، واطمأن فاري، وكأني أنظر إلى عرش ربي بارزا،

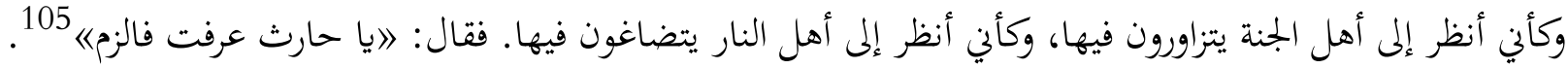

- محمد بن عبد الله الحضرمي، روى عنه الطبراين، مات سنة 277هـ. قال الذهبي في السير: "الشيخ، الحافظ، الصادق، محدث الكوفة، صنف المسند والتاريخ، وكان متقنا" 106.

102 أبو نعيم، أخبار أصبهان، محقق سيد كسروي حسن، (بيروت: دار الكتب العلمية، د.ط، د.ت)، ج169، ص169، ص162.

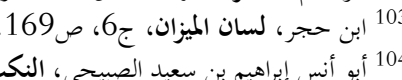

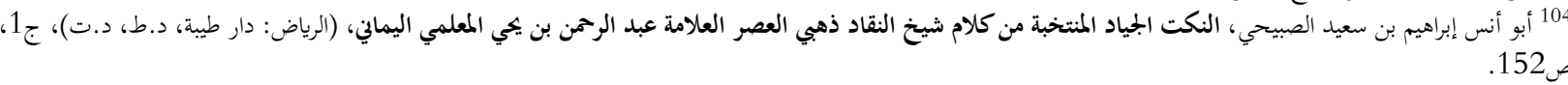
105

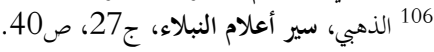


- ـ محمد بن العلاء بن كريب الهمداني، روى عنه محمد بن عبد الله، ومات سنة 247هـ 107 . قال ابن حجر في

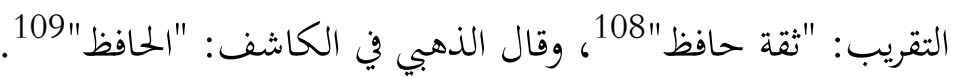

- زيد بن الحباب بن الريان، روى عنه محمد بن العلاء، ومات سنة 230هـ 110 . قال ابن حجر في التقريب:

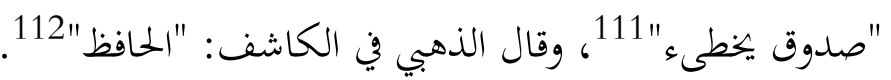

- عبد الله بن لهيعة، روى عنه زيد بن الحباب بن الريان، ومات سنة 174هـ 113 لـ قال ابن حجر في التقريب:

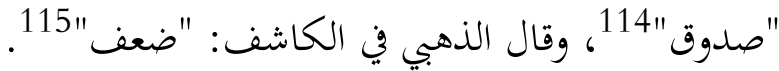

- - خالد بن يزيد الجمحي المصري، روى عنه عبد الله بن لهيعة، مات سنة 139هـ 116 فال قال ابن حجر في التقريب:

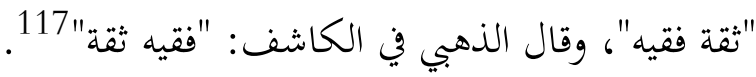

- ـ سعيد بن أبي هلال، روى عنه خالد بن يزيد، ومات سنة بعد 130هـ 118 فال قال ابن حجر في التقريب:

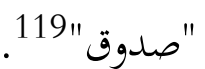

- محد بن أبي الجهم العدوي، روى عنه سعيد بن أبي هلال الليثي، ومات سنة 63هـ. قال ابن حجر في

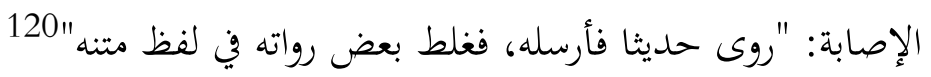

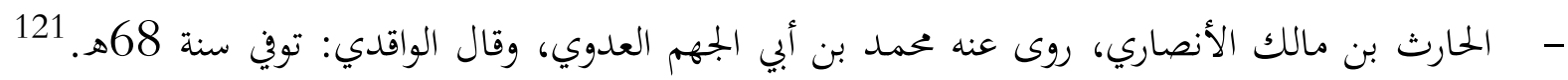
المعروف بالصحابة".

تخريجه

أخرجه الشجري الجرجاني عن الطبراني عن محمد بن عبد الله الحضرمي عن أبو كريب عن زيد بن الحباب مثله 122، أخرجه البيهقي عن أبو عبد الرحمن السلمي عن علي بن الفضيل بن محمد بن عقيل عن مطين عن محمد بن العلاء عن زيد بن الحباب مثله 123.

شواهده

حديث أنس بن مالك، أخرجه البيهقي في الشعب قال أخبرنا أبو محمد الحسن بن علي بن المؤمل الماسرجسي ثنا

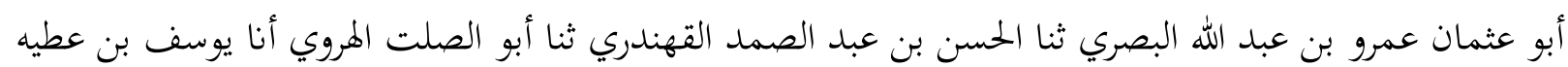

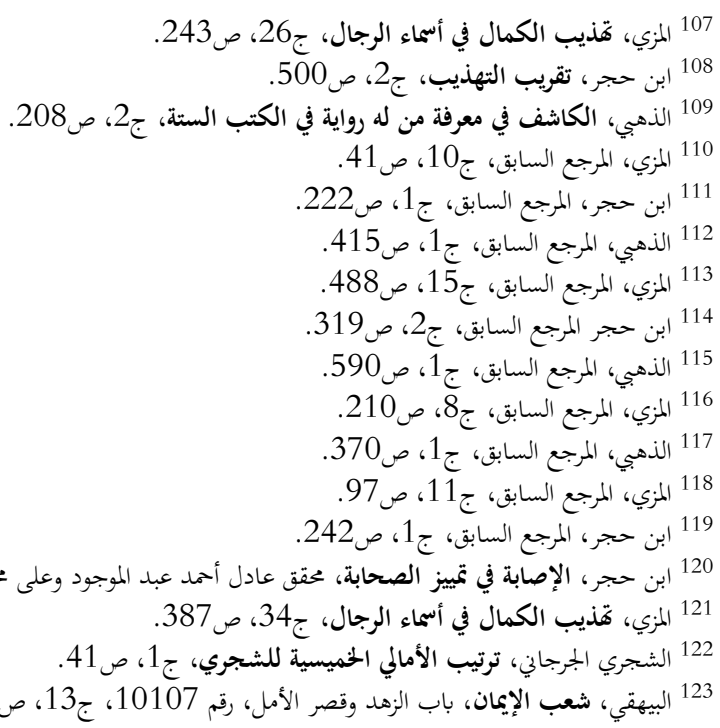

TAHDIS Volume 11 Nomor 2 Tahun 2020 
ثنا ثابت عن أنس بن مالك: أن رسول الله صلى الله عليه وسلم خرج يوما فاستقبله شاب من الأنصار يقال له:

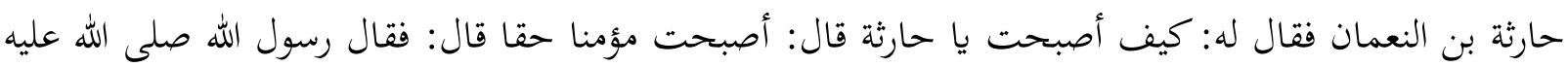

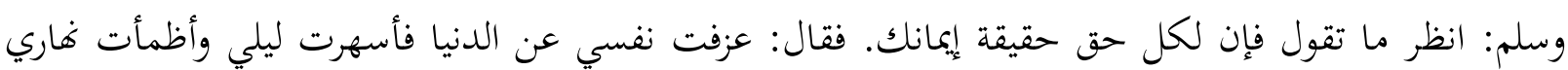

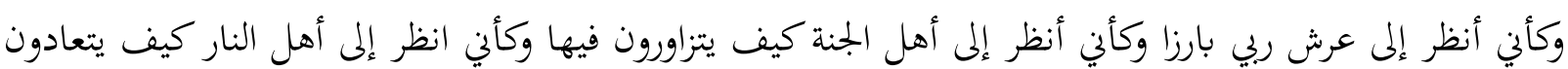
فيها

حكمه

الحديث بهذا السند ضعيف، وعلته عبد الله بن لميعة وهو ضعيف، كما قال ابن معين وغيره: لا يحتج بحديثه، وقال

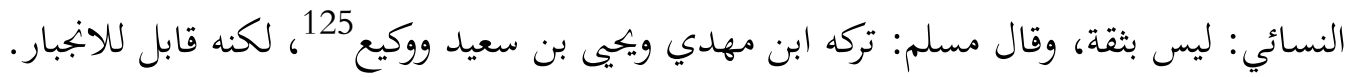

من فوائده المؤمن يعلم من نفسه أنه لا يكذب الله ورسوله يقينامُ126.

\section{V}

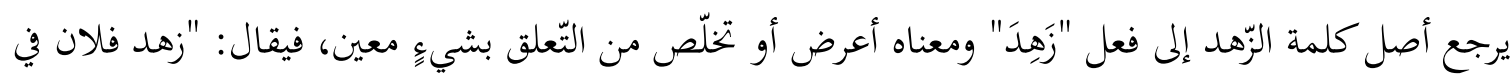

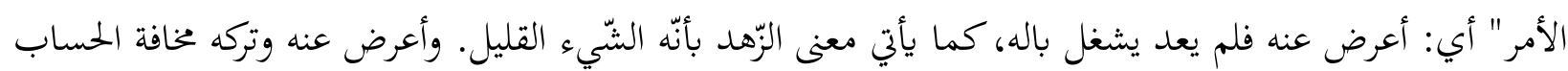

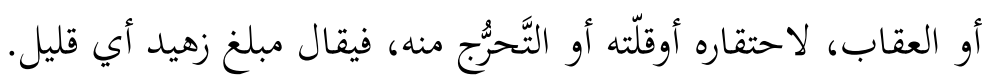

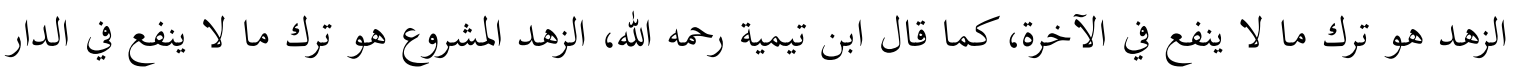

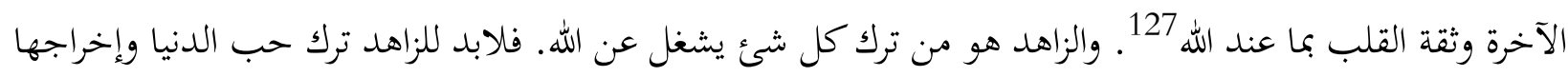

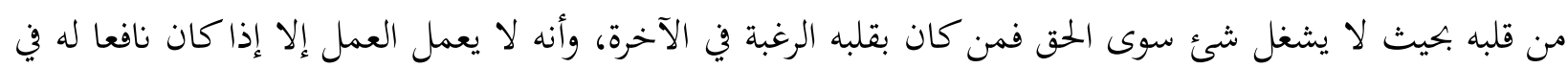

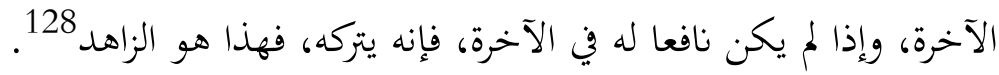
منهوم الزهد

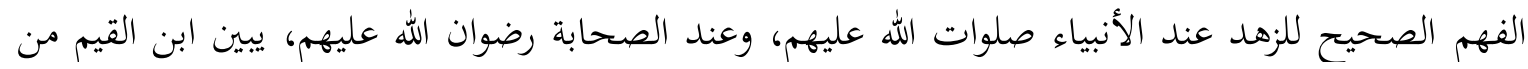

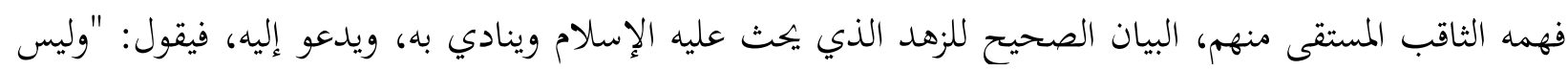

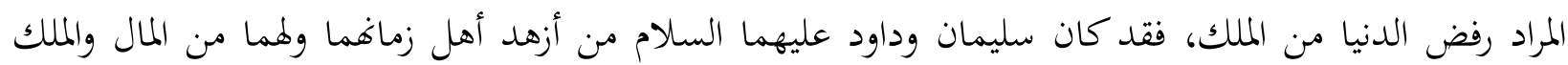
والنساء.

وكان نبينا صلى الله عليه وسلم من أزهد البشر على الإطلاق، وله تسع نسوة، وكان علي بن أبي طالب، وعبد ألمان

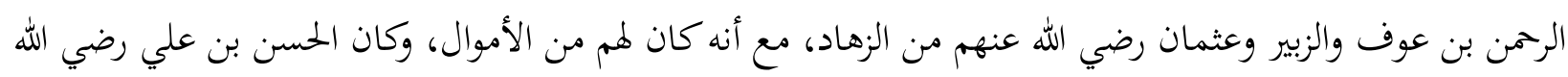

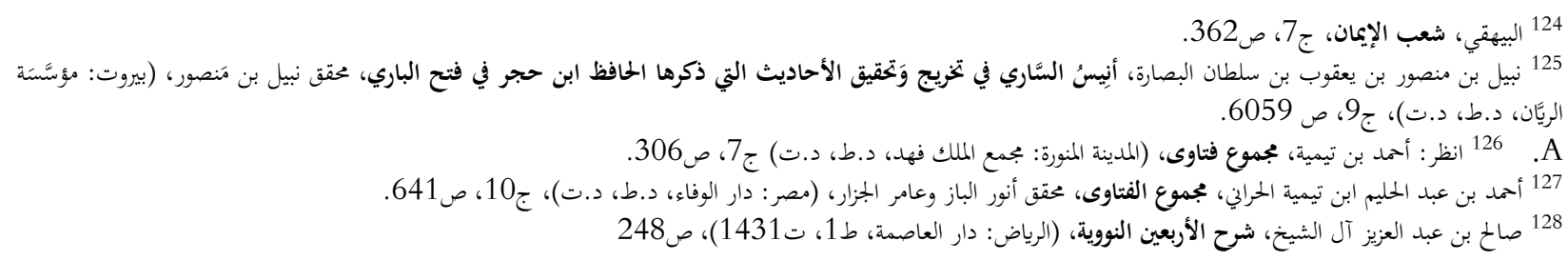


عنه من الزهاد، مع أنه كان من أكثر الأمة محبة للنساء ونكاحًا لهن، وأغناهم، وكان عبد الله بن المبارك من الأئمة الزهاد مع مال كثير، وكذلك الليث بن سعد من أئمة الزهاد.

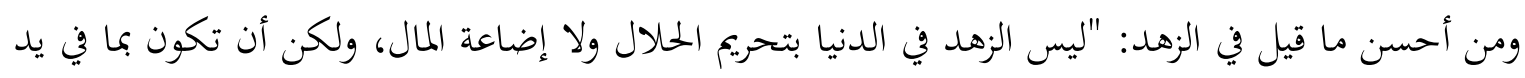

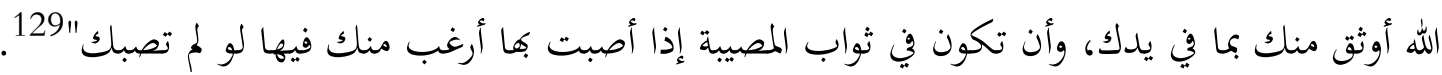
ولو تتبعنا الشروط الواجبة في الزاهد بحسب أقوال من ذاقوا الزهد واتخذوه منهاجًا لهم ما انتهينا، وسأكتفي هنا بما ذكره الإمام الحافظ الزاهد محيي الدين أبو زكريا يهيى بن شرف المشهور بالنووي في الزهد، فقد قال: "فمن أنس أخرج من قلبه حب الرياسة في الدنيا والترفع فيها على الناس، فهو الزاهد حقا، وهذا هو الذي يستوي عنده حامده وذامه في

حقيقة الزهد

والزهد في الدنيا هو ما كان عليه رسول الله وأصحابه. فهو ليس بتحريم الطيبات وتضييع الأموال، ولا بلبس المرقع من الثياب، ورث والملابس، كريه الرائحة، حاله وسخ ينفر كل من يراه، ولا بالجلوس في البيوت وانتظار الصدقات.

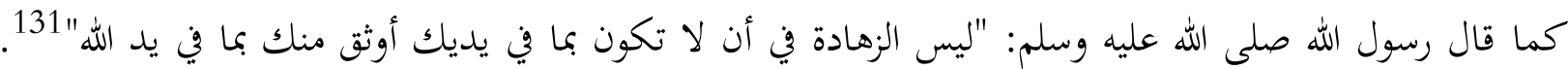

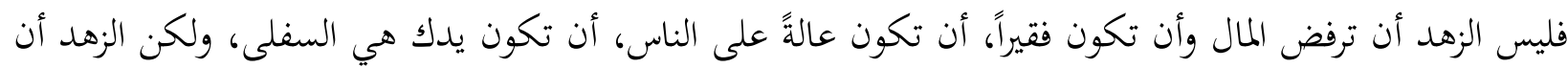

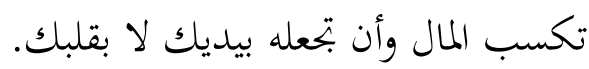

فلو نظرنا إلى العشرة المبشرين بالجنة لوجدنا أن أكثرهم كانوا من أصحاب رؤوس الأموال الطائلة ومن التجار،

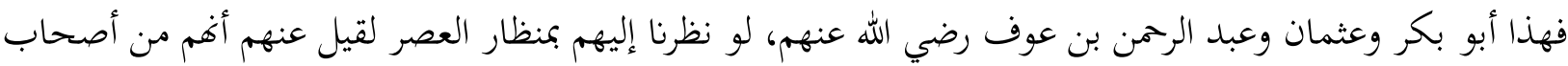
الملايين، فهل تخلف أحدهم عن غزوة مع رسول الله هل أهاهم التكاثر فمنعوا الإنفاق في سبيل الله كلا و الله ثم كلا، هل سعوا للرئاسة والتفاخر وتزكية النفس وطلب المدح؟ لا و الله ما فعلوا، بل هم أبعد الأمة عن هذه الأمور، وكانوا يجودون بأموالهم وأنفسهم في سبيل الله ولنصرة دينه ولنصرة النبي صلى الله عليه وسلم 132. ليس الزهد لبس المرقع من الثياب، ولا اعتزال الناس والبعد عن المجتمع، ولا صيام الدهر، فيإن النبي صلى الله عليه وسلم سيد الزاهدين، وكان يلبس الجديد من الثياب، ويتزين للوفود وفي الجمع والأعياد، ويخالط الناس، ويدعوهم إلى الخير ويعلمهم أمور دينهم، وكان ينهى أصحابه رضي الله عنهم عن صيام الدهر، مثل رسول الله صلى الله عليه

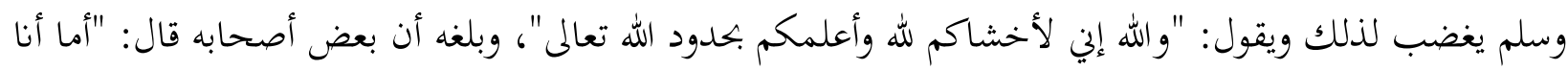
فأصوم فلا أفطر"، وقال الآخر: "أما أنا فأقوم فلا أنام"، وقال آخر: "أما أنا فلا أتزوج النساء" وقال وقال الآخر : "أما أنا فلا آكل اللحم" فقال صلى الله عليه وسلم: "لكني أصوم وأفطر وأقوم وأنام وأتزوج النساء وآكل اللحم، فمن رغب وأب عن سنتي فليس مني. وليس كل ما تقواه النفس يُذم، وليس كل ما يُتزين به للناس يكره، وإنما يُنهى عن ذلك إذا كان الشرع قد فهى عنه، أو على وجه الرياء في باب الدِّين. فإن الإنسان يجب أن يُرى جميلاً، وذلك حظ للنفس لا يلام فيه، ولذذا يسرّح

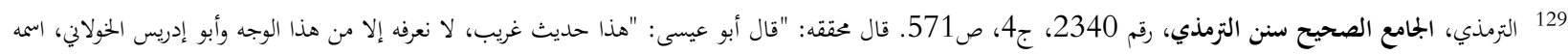

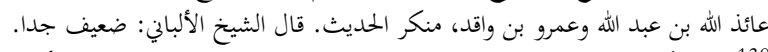

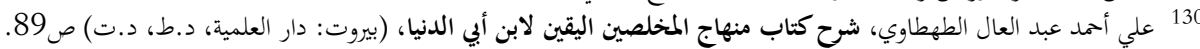

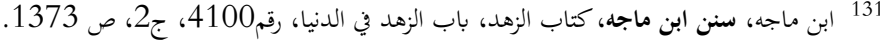

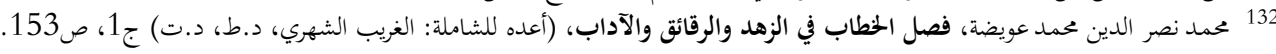


شعره، وينظر في المرآة، ويسوِّي عمامته، ويلبس بطانة الثوب الخشنة إلى داخل، وظهارته الحسنة إلى خارج، وليس في شيء من هذا ما يكره، ولا يذم.

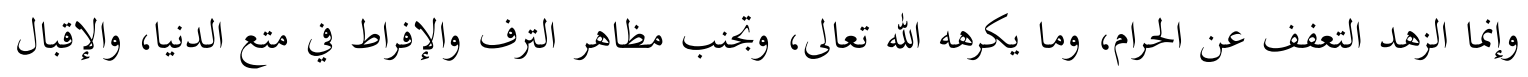

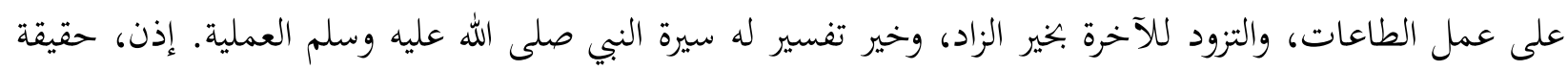

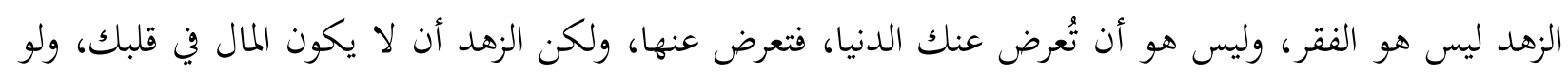

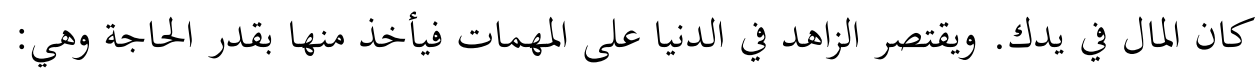

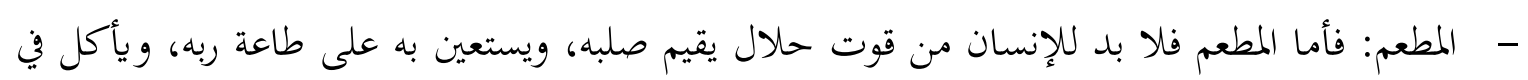
اليوم والليلة في النوع والمقدار والحال كما كان صلى الله عليه وسلم يأكل لمالما إمام الزهاد.

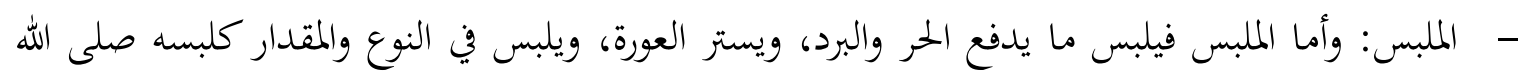
عليه وسلم. - المسكن: فيسكن بيتاً على قدر حاجته من غير زيادة، ولا زينة، ولا إسراف، وأما أثاث البيت فيكون بقدر حاجته، ولا يأنف من الدون من الأثاث.

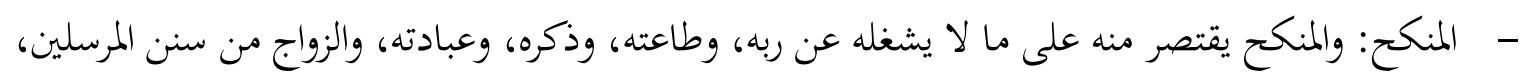
فلا غنى له عنه إلا من علة.

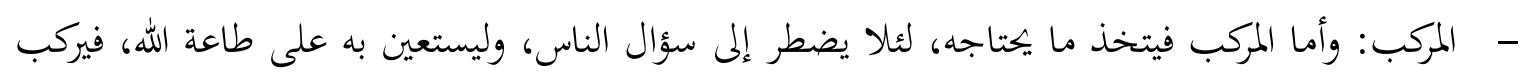

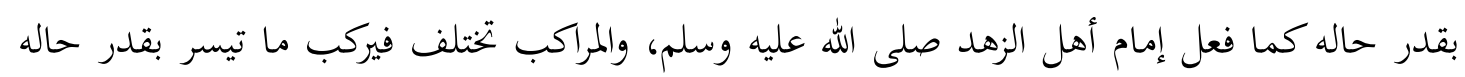

$$
\text { من دابة أوسيارة. }
$$

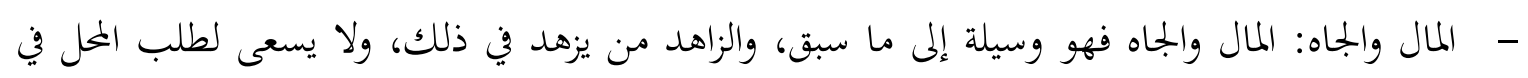

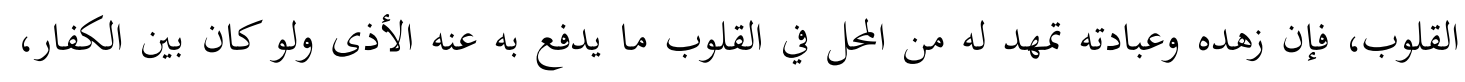
فكيف وهو بين المسلمين.

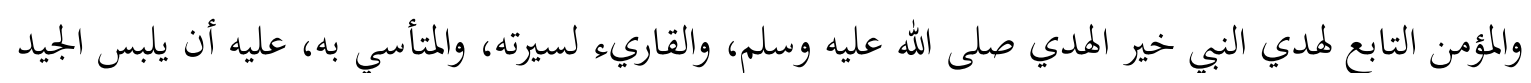

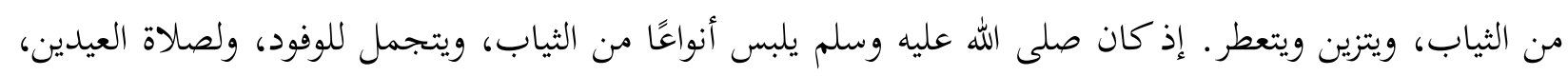
ولصلاة الجمعة، مع البعد عن الإسراف والكبرياء 133.

\section{VI}

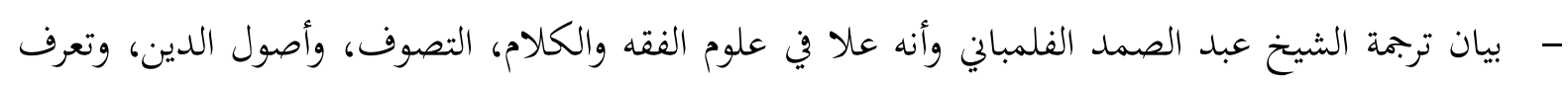

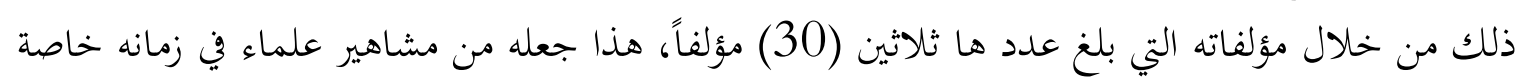

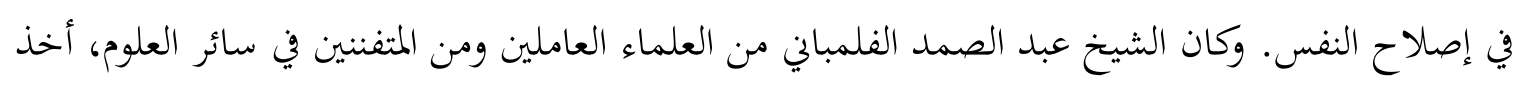

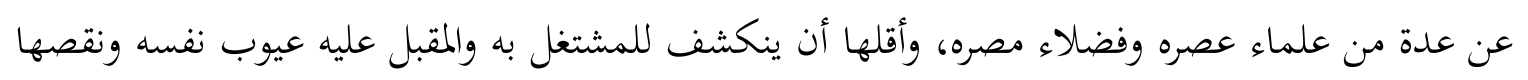


وتقصيرها، ويكون ذلك بعد توفيق الله سبحانه عاصماً له عن الغرور. أنه قد كثر من زمن الأولين الاعتناء والمطالعة في كتاب إحياء علوم الدين.

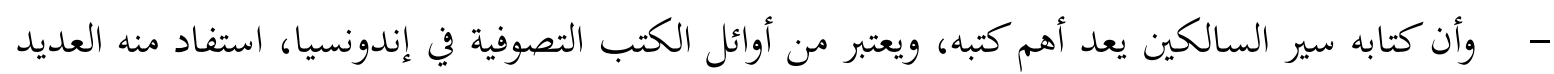
من العلماء منذ يوم تأليفه إلى يومنا هذا.

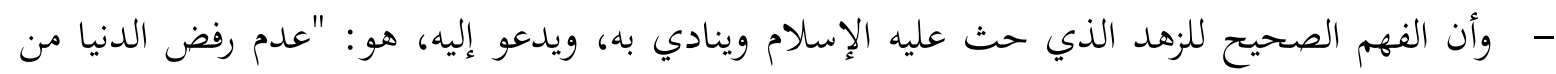

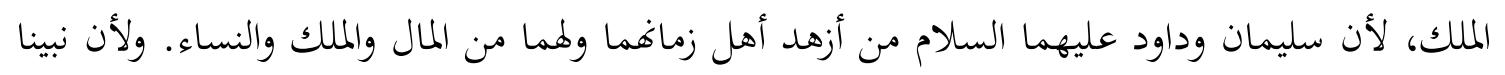

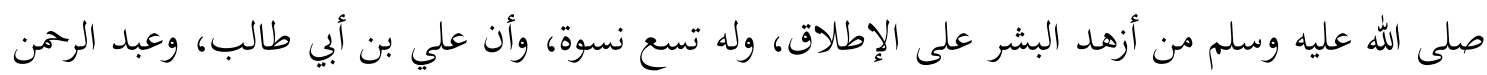

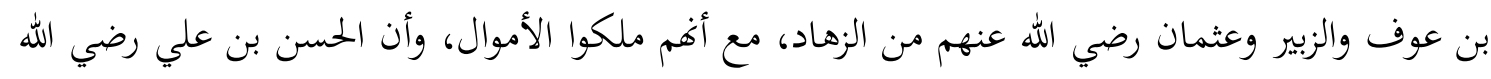

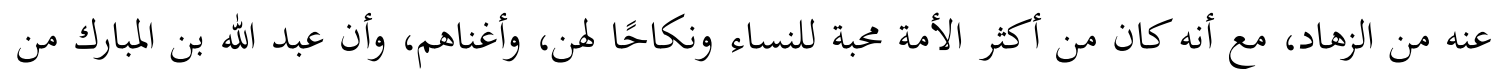

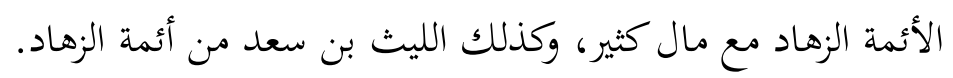

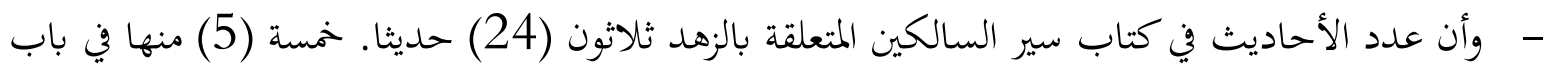

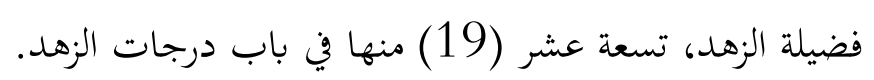

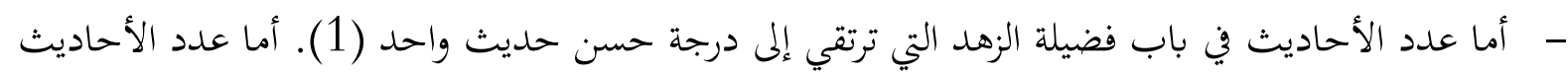

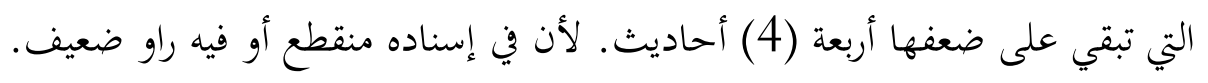




\section{المراجع}

القران الكريم

ابن تيمية الحرائ، أحمد بن عبد الحليم. (د.ت). مجموع الفتاوى. تحقق: أنور الباز وعامر الجزار. مصر: دار الوفاء،

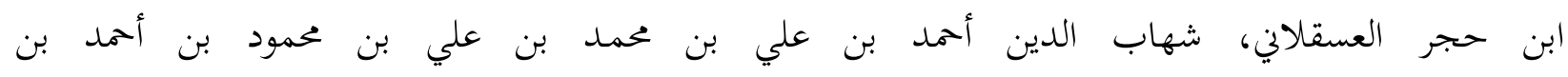

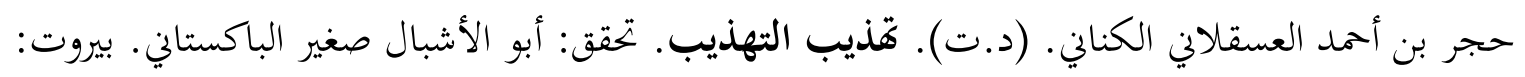

$$
\text { دار العاصمة، (د.ط). }
$$

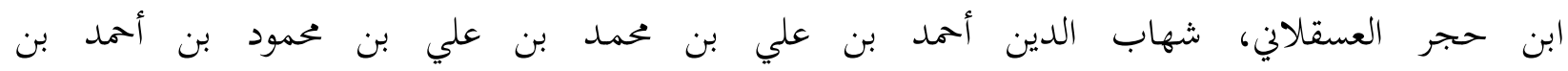

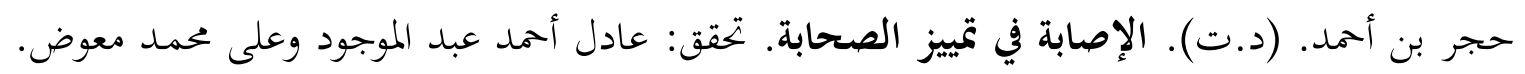

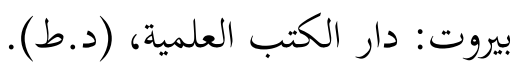

ابن دينار البغدادي، أبو الحسن علي بن عمر بن أحمد بن مهاب بن مسعود بن النعمان. (د.ت). تعليقات الدارقطني على الجزوحين لابن حبان. تحقق: خليل بن محمد العربي. القاهرة: دار الكتاب الإسلامي، (د.ط).

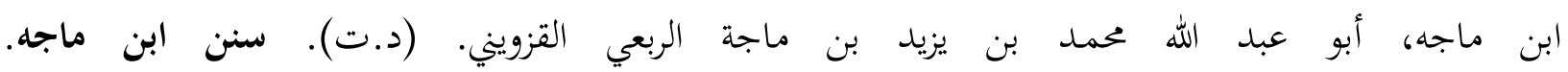

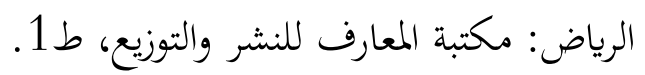

ابن مبارك الدوسري، راجس. (د.ت). الزهد في شعر ابن الرومي دراسة موضوعية. المملكة العربية السعودية: جامعة

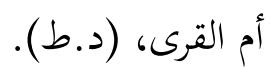

أبو أنس، إبراهيم بن سعيد الصبيحي. (د.ت). النكت الجياد المنتخبة من كلام شيخ النقاد ذهبي العصر العلامة

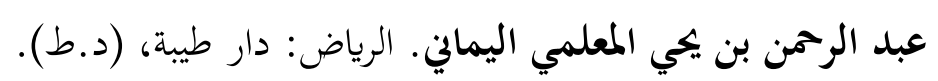

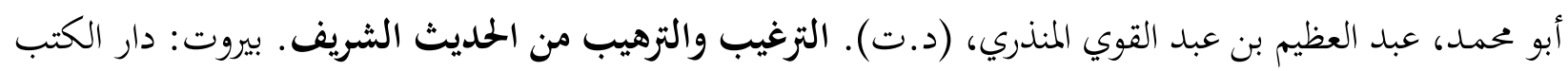

$$
\text { العلمية، (د.ط). }
$$

أبو نعيم، أحمد بن عبد الله الأصبهاني. (1410هـ). حلية الأولياء وطبقات الأصفياء، بيروت: دار الكتاب العربي، .4b

أغا النقلي الدمشقي، محمد منير بن عبده. (د.ت). الإتحافات السنية بالأحاديث القدسية. بيروت: دار ابن كثير،

البيطار الميداني الدمشقي، عبد الرزاق بن حسن بن إبراهيم. (د.ت). حلية البشر في تاريخ القرن الثالث عشر.

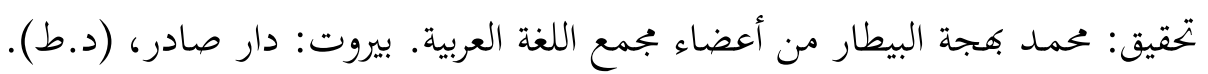
البيهقي، أبي بكر أحمد بن الحسين بن على البيهقي. (2003م). شعب الإيمان. تحقيق: عبد العلي عبد الحميد حامد.

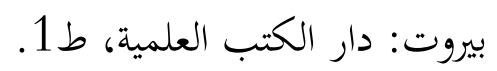

الجبرتي، عبد الرحمن بن حسن. (د.ت). تاريخ عجائب الآثار في التراجم والأخبار. بيروت: دار الجيل، (د.ط). 
الحاكم النيسابوري، محمد بن عبد الله أبو عبد الله. (د.ت). المستدرك على الصحيحين، تحقق: مصطفى عبد القادر عطا. بيروت: دار الكتب العلمية (د.ط).

الذهبي، أبو عبد الله شمس الدين محمد بن أحمد بن عثمان بن قايماز. (د.ت). تاريخ الإسلام وَوَفيات المشاهير وَالأعلام. تحقق: بشار عوّاد معروف. السعودية: دار القبلة للثقافة الإسلامية، (د.ط).

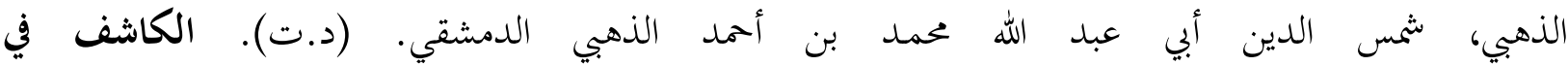
معرفة من له رواية في الكتب الستة. تعليق: محمد عوامة. جلدة: دار القبلة للثقافة

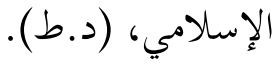

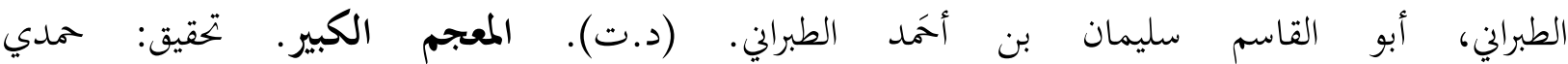
عبد المجيد السلفي. القاهرة: مكتبة ابن تيمية، (د.ط).

الطهطاوي، علي أحمد عبد العال. (د.ت). شرح كتاب منهاج المخلصين اليقين لابن أبي الدنيا. بيروت: دار العلمية، (b.د)

عيسى الترمذي، بن عيسى حمدد. (د.ت). الجامع الصحيح سنن الترمذي. دار الغرب الإسلامي: بيروت، د.ط،

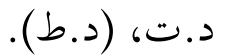

الفلمباني، عبد الصمد الفلمباني. (د.ت). سير السالكين في طريقة السادات الصوفية. إندونيسيا: دار الفكر، (b.د)

الكلاباذي البخاري، أبو بكر محمد بن أبي إسحاق إبراهيم بن يعقوب. (د.ت). بحر الفوائد المشهور بمعاني الأخبار.

$$
\text { بيروت: دار الكتب العلمية، (د.ط). }
$$

محمد عويضة، محمد نصر الدين. (د.ت). فصل الخطاب في الزهد والرقائق والآداب. أعده للشاملة: الغريب

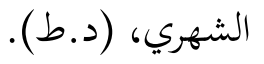

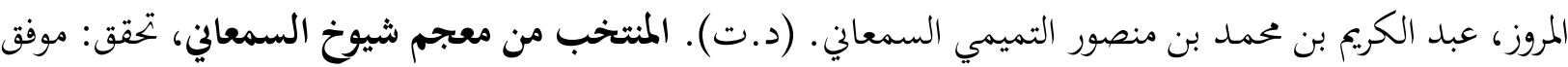

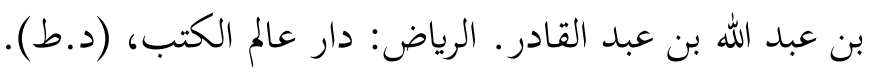

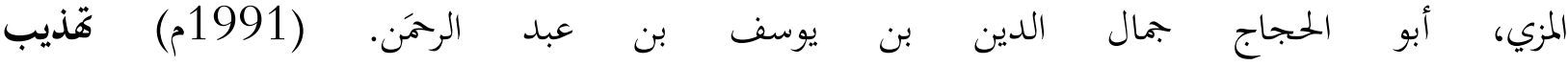
الكمال في أسماء الرجال. تحقق: بشار عواد معروف. بيروت: مؤسسة الرسالة، (د.ط).

الجرجاني، إسماعيل بن زيد الحسني الشجري. (د.ت). تحقق محمد حسن إسماعيل، توتيب الأمالي الخميسية للشجري.

$$
\text { بيروت: دار الكتب العلمية، (د.ط). }
$$

$$
\text { وكيع، ابن الجراح الرؤاسي. (د.ت). الزهد. المدينة المنورة: مكتبة الدار، (د.ط). }
$$

Azyumardi Azra, Jaringan Ulama Timur Tengah dan Kepulauan Nusantara Abad 18 dan 19, (Jakarta: Mizan 2004).

Azyumardi Azra, The Origin of Islamic Reformism in Southeast Asia Network of Malaysia Indonesian and Middle Eastern Ulama in The Seventeenth and Eighteenth Centuries, Production Sdn Bhd 2004 
أحاديث فضيلة الزهد في كتاب سَيْر السالكين للشيخ عبد الصمد الفَلمِبْبَانِ | 44

Ensiklopedi Islam di Indonesia, Direktorat Jendral Pembinaan Kelembagaan Agama Islam Proyek Peningkatan Prasarana dan Sarana Perguruan Tinggi Agama Islam, (Jakarta: Institut Agama Islam Negri 1993.

Hj. W. Muh. Shaghir Abdullah, Syeikh Abdush Shamad Al-Palimbani Ulama Shufi dan Jihad Melayu, (Kuala Lumpur: Dewan Bahasa dan Pustaka, 1996.

M.H. Dato Kerani Muhammad Arsyad, Silsilah Negri Kedah, (Kuala Lumpur, Dewan Bahasa dan Pustaka, 1968. 